University of Tennessee Health Science Center UTHSC Digital Commons

$5-2009$

\title{
Studying the Specificity of hPXR Antagonists Using a Panel of Cell-based Assays
}

Fang Lei
University of Tennessee Health Science Center

Follow this and additional works at: https://dc.uthsc.edu/dissertations

Part of the Medical Cell Biology Commons

\section{Recommended Citation}

Lei, Fang , "Studying the Specificity of hPXR Antagonists Using a Panel of Cell-based Assays" (2009). Theses and Dissertations (ETD). Paper 143. http://dx.doi.org/10.21007/etd.cghs.2009.0179.

This Thesis is brought to you for free and open access by the College of Graduate Health Sciences at UTHSC Digital Commons. It has been accepted for inclusion in Theses and Dissertations (ETD) by an authorized administrator of UTHSC Digital Commons. For more information, please contact jwelch30@uthsc.edu. 


\title{
Studying the Specificity of hPXR Antagonists Using a Panel of Cell-based Assays
}

\author{
Abstract \\ indentified as non-toxic hPXR antagonists. \\ Document Type \\ Thesis \\ Degree Name \\ Master of Science (MS) \\ Program \\ Biomedical Sciences \\ Research Advisor \\ Taosheng Chen, Ph.D. \\ Keywords \\ Antagonist; Human PXR; Reporter Gene Assay \\ Subject Categories \\ Medical Cell Biology | Medical Sciences | Medicine and Health Sciences
}

The pregnane $X$ receptor (PXR or SXR; NR1I2) is a member of the nuclear receptor superfamily. It activates the transcription of a large network of genes including cytochrome P450 (CYP) and Mdr1 which play critical roles in chemicals metabolism and transportation. Induction of CYPs contributes to adverse drug-drug interactions. Non-toxic, PXR-specific antagonists will be valuable in attenuating the adverse drug-drug interaction which is the cause of many treatment failures in clinic. However, few hPXR antagonists were reported particularly the specific ones. In this thesis a reporter gene assay was used to study the specificity of hPXR antagonists from a panel of compounds that have been previously 


\title{
STUDYING THE SPECIFICITY OF hPXR ANTAGONISTS USING A PANEL OF CELL-BASED ASSAYS
}

\author{
A Thesis \\ Presented for \\ The Graduate Studies Council \\ The University of Tennessee \\ Health Science Center \\ In Partial Fulfillment \\ Of the Requirements for the Degree \\ Master of Science \\ From The University of Tennessee
}

By

Fang Lei

May 2009 
Copyright (C 2009 by Fang Lei All rights reserved 


\section{DEDICATION}

This thesis is dedicated to my husband, Zhiyong Liu and

my parents

for their love and support. 


\section{ACKNOWLEDGEMENTS}

First, I would like to thank my research mentor, Dr. Taosheng Chen, for his guidance, support and help during the course of this research work. His encouragement of me involved in the project and the lessons I've learned will benefit me a lifetime.

I would like to thank my committee member Dr. David R. Nelson who gave me many insightful suggestions on my research and thesis writing. I would also like to thank other two committee members Dr. Bing Yan and Dr. Xin Zhang for their advice and help.

My special thanks to Wenwei Lin, who helped me start this project and provided me many helpful suggestions and discussion, and Jimmy Cui, who helped operating and maintaining all the automatic systems. I would also like to thank all other lab members that I have been working with. They have made my research in the lab an enjoyable one.

Finally, I would like to thank the Integrated Program of Biomedical Sciences of University of Tennessee Health Science Center for providing financial assistant for my graduate study. Thank all the faculty and staff in IPBS, especially Dr. Patrick Ryan and Janie K. Van Prooijen for their help and support during my graduate education. 


\begin{abstract}
The pregnane X receptor (PXR or SXR; NR1I2) is a member of the nuclear receptor superfamily. It activates the transcription of a large network of genes including cytochrome P450 (CYP) and Mdr1 which play critical roles in chemicals metabolism and transportation. Induction of CYPs contributes to adverse drug-drug interactions. Nontoxic, PXR-specific antagonists will be valuable in attenuating the adverse drug-drug interaction which is the cause of many treatment failures in clinic. However, few hPXR antagonists were reported particularly the specific ones. In this thesis a reporter gene assay was used to study the specificity of hPXR antagonists from a panel of compounds that have been previously indentified as non-toxic hPXR antagonists.
\end{abstract}




\section{TABLE OF CONTENTS}

Chapter 1. Introduction...........................................................................................................1

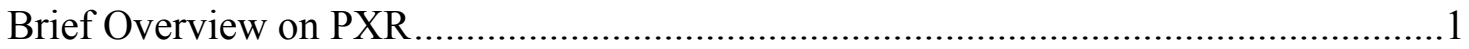

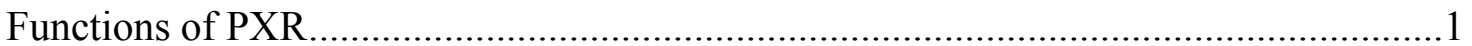

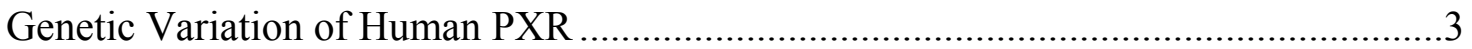

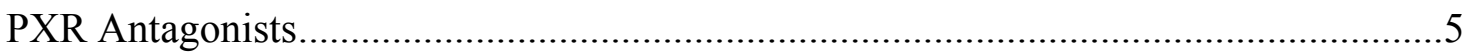

Crosstalk between PXR and other Nuclear Receptors................................................6

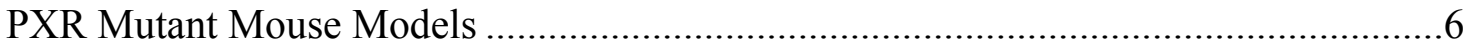

Chapter 2. Materials and Methods.........................................................................9

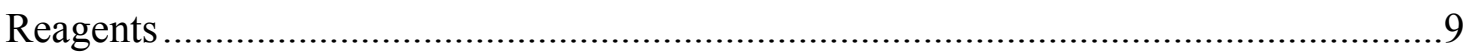

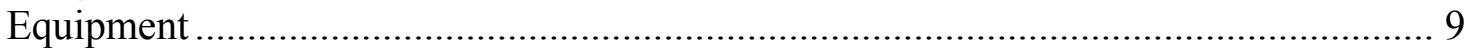

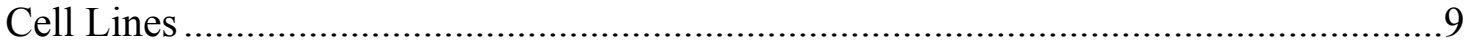

Mycoplasma Detection Assay.............................................................................. 9

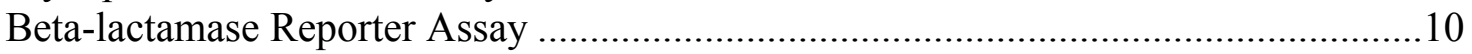

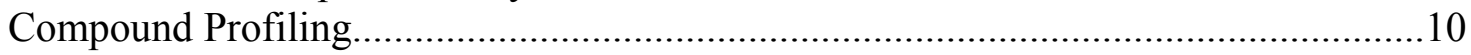

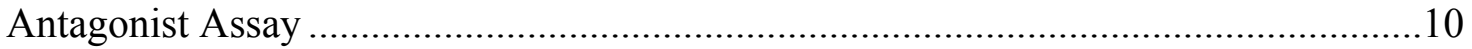

Chapter 3. Determing the Specificity of hPXR Antagonists ............................................11

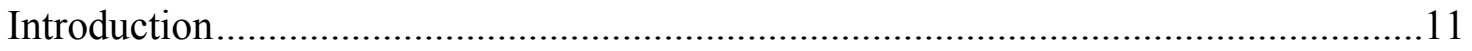

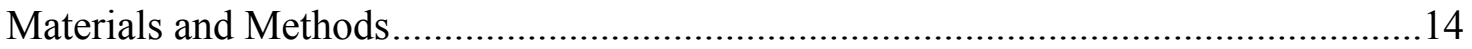

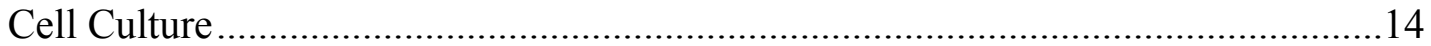

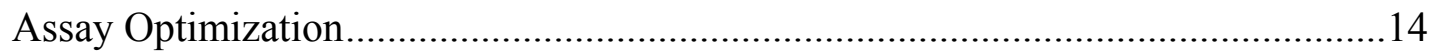

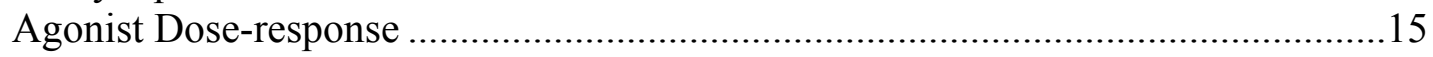

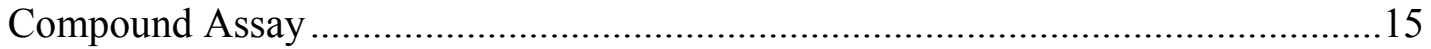

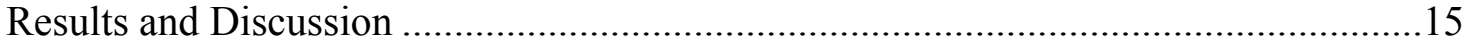

Assay Performance under Variable Conditions.......................................................15

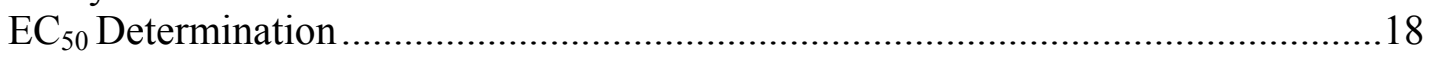

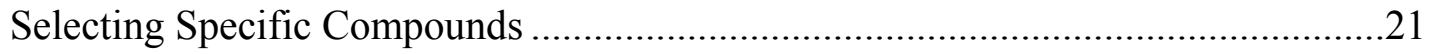

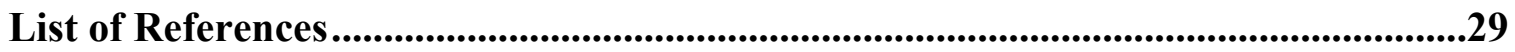

Appendix. Supplemental Data for Chapter 3 ...................................................................... 32

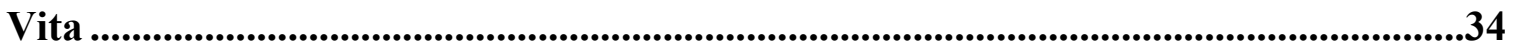




\section{LIST OF FIGURES}

Figure 1-1. Schematic representation of hPXR multi-domain structure ..........................2

Figure 1-2. Schematic representation of hPXR function.............................................4

Figure 1-3. Phylogenetic tree of human nuclear receptors (from Wikipedia)...................7

Figure 3-1. Schematic representation of GeneBLAzer nuclear receptor cell lines ...........12

Figure 3-2. Schematic illustration of FRET assay (Invitrogen protocol) ........................13

Figure 3-3. Assay performance with different cell density and substrate loading time ....17

Figure 3-4. Dose response of the nuclear receptor to its primary agonist .......................20

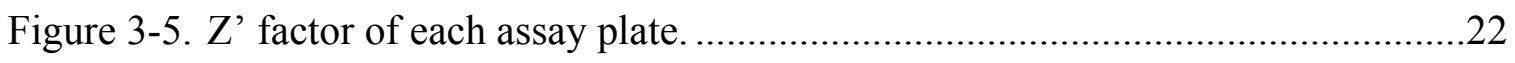

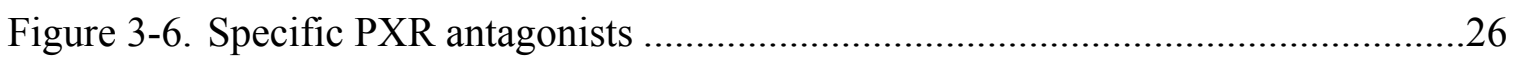

Figure 3-7. Compounds that showed inhibition activity to all cell lines in the assay .......27

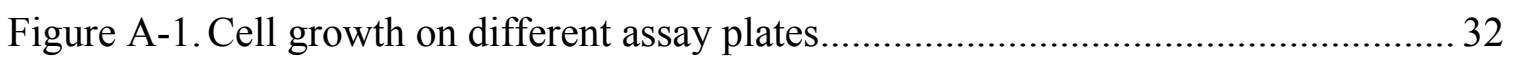

Figure A-2. Dose response curve of CDCA to FXR ................................................ 33 


\section{Chapter 1. Introduction}

\section{Brief Overview on PXR}

Mouse Pregnane X receptor (PXR or SXR; NR1I2), a member of the nuclear receptor (NRs) superfamily [1-3], was first cloned and identified in 1998 [4]. The human PXR (hPXR) was found subsequently and named steroid and xenobiotic receptor (SXR) or pregnane-activated receptor (PAR) $[5,6]$.

PXR is composed of four independent but interacting functional modules (Figure 1-1), which include, from $\mathrm{N}$-terminus to $\mathrm{C}$-terminus, the modulator domain, the DNA-binding domain (DBD), the hinge region and the ligand-binding domain (LBD) [7]. Among these domains, DBD mediates the sequence-specific binding to the "response element" of its target gene while LBD mediates the ligand-binding, dimerization to other NRs or homodimerization and ligand-independent repression [8].

PXR has at least three isoforms, PXR.1, PXR.2 and PXR.3. PXR.1 is the most abundantly expressed isoform in human tissue. It can be activated by structurally diverse lipophilic ligands. PXR.2 mRNA which represents 6.7\% of total PXR mRNA transcripts is 111 nucleotides shorter than PXR.1, resulting in a deletion of 37 amino acids from the PXR LBD. PXR.3 is 41 amino acids shorter than PXR.1 because the 123 nucleotide region located in the putative LBD is lost. Due to the lack of the 41 amino acids, PXR.3 has a more restricted activation profile than PXR.1 [4]. For example, dexamethasone, dexamethasone-t-butyl-acetate, dexamethasone-21-acetate and the pregnenolone derivative 6,16 $\alpha$-dimethyl pregnenolone can activate PXR.1. However, among those steroids, only dexamethasone-t-butyl-acetate is able to activate PXR.3. Homologous comparisons of PXR.3 with different members of nuclear receptors indicate that PXR is most like Xenopus laevis orphan nuclear receptor $1(\mathrm{ONR} 1)$ and mammalian vitamin $\mathrm{D}$ receptor (VDR) $[9,10]$.

Both PXR.1 and PXR.2 are highly expressed in liver and intestine of embryo and adult, and are expressed at a lower level in adult kidney and stomach, but are undetectable in other organs $[4,11]$. This specific distribution of PXR is highly correlated to its versatile functions in regulating dynamic metabolism of a large number of endogenous or exogenous nutrients, drugs or other chemicals, because liver and intestine are the main organs where many xenobiotics and endobiotics are digested, absorbed, and selectively eliminated [11].

\section{Functions of PXR}

Generally speaking, PXR can be regarded as an internal sensor for the alterations of xenobiotics and endobiotics. Upon binding with diverse natural or synthesized ligands, it will form herterodimers with retinoid $X$ receptor (RXR). PXR and RXR heterodimer then will probe and bind to the PXR response elements that are located in the 5' end of the 


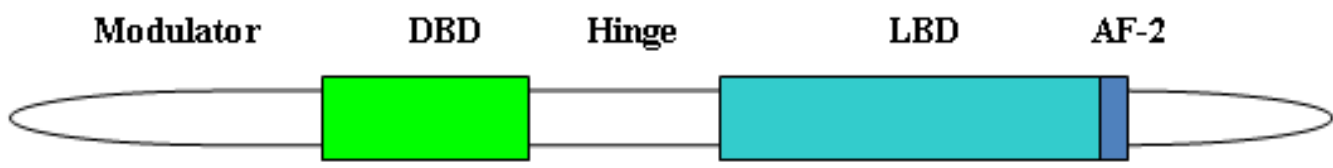

Figure 1-1. Schematic representation of hPXR multi-domain structure. hPXR has a multi-domain structure which includes a modulatory A/B domain, the DNA-binding domain ( $\mathrm{C}$ domain), the hinge $\mathrm{D}$ domain and the ligand-binding domain (E domain) which contains a shallow activation function 2 (AF-2) surface essential for liganddependent interactions with transcriptional coregulators. 
PXR target genes (Figure 1-2). PXR can either promote or block the transcription of targeted genes which include but are not limited to P450s from CYP3A and CYP2B, transporters such as P-glycoprotein, multidrug resistance-related protein-3, and organic anion transporting polypeptide-2 (OATP2) [12-15]. PXR is so important in regulating metabolic enzymes and transporters that it inevitably is able to affect the speed at which different drugs are digested, absorbed, and eliminated from the body. If different drugs are used at the same time and some drugs happen to be PXR ligands with high affinities, drug-drug interactions will happen. Drug-drug interactions could accelerate dynamics of the drugs which are the substrates of PXR targeted genes-encoded enzymes and lead to adverse effects including death.

Three examples are given here to demonstrate the roles of PXR in drug-drug interactions. The first instance is Rifampicin, a drug for long term tuberculosis treatment [16]. Moreover, Rifampicin is a human PXR ligand as well. As mentioned previously, PXR can regulate CYP3A which can metabolize a lot of drugs which include anti-HIV protease inhibitors, oral contraceptives, and midazolam [17-19]. The second example is the drug-drug interactions between St John's Wort, an old herbal medicine for mental disorders and nerve pain, and Cyclosporine, an immunosuppressant used in patients who received organ transplantation to prevent organ rejection. It has been found that components of St John's Wort contain multiple PXR ligands so that CYP3A activated by PXR will speed up cyclosporine metabolism and will lead to transplantation failure [20]. The third example is that isoniazid and 3-methylcholanthrene can accelerate the metabolism of Acetaminophen (APAP) and cause accumulation of the alkylating metabolite $N$-acetyl- $p$-benzo-quinone imine (NAPQI) and result in liver damage in a PXR-dependent manner [21-23]. Recently, several traditional Chinese medicine (TCMs) have also been implicated in drug-drug interactions [24, 25].

In addition to the xenobiotic functions such as drug-drug interactions discussed already, PXR also have important roles in the endobiotic dynamics. Such endobiotic associated functions include regulating bile acid detoxification and cholestasis, bilirubin detoxification and clearance, adrenal steroid homeostasis and drug-hormone interactions, lipid metabolism, inflammation and inflammatory bowel disease, bone homeostasis, and retinoic acid metabolism, all of which functions as intensively reviewed[11, 26]. PXR activation also up-regulates other drug transporter genes, like Mdr1, Mrp2 and Mrp3 [27]. Not only does PXR regulate the expression of so many genes, it also interplays with many other nuclear receptors and affects the transcriptional activity thus the expression of their target genes. The nuclear receptors that crosstalk with PXR include FXR, GR, CAR, VDR, etc.

\section{Genetic Variation of Human PXR}

The $h P X R$ gene contains 9 exons, and all exons except exon 1 contain coding regions. It is located on chromosome 3q12q13.3, with $38 \mathrm{~kb}$ length [28]. Similar to mouse PXR, $\mathrm{hPXR}$ has a few variants. In addition to the three main variants, hPXR.1, hPXR.2 and hPXR.3, there are 7 more splice variants with low expression frequency and with 


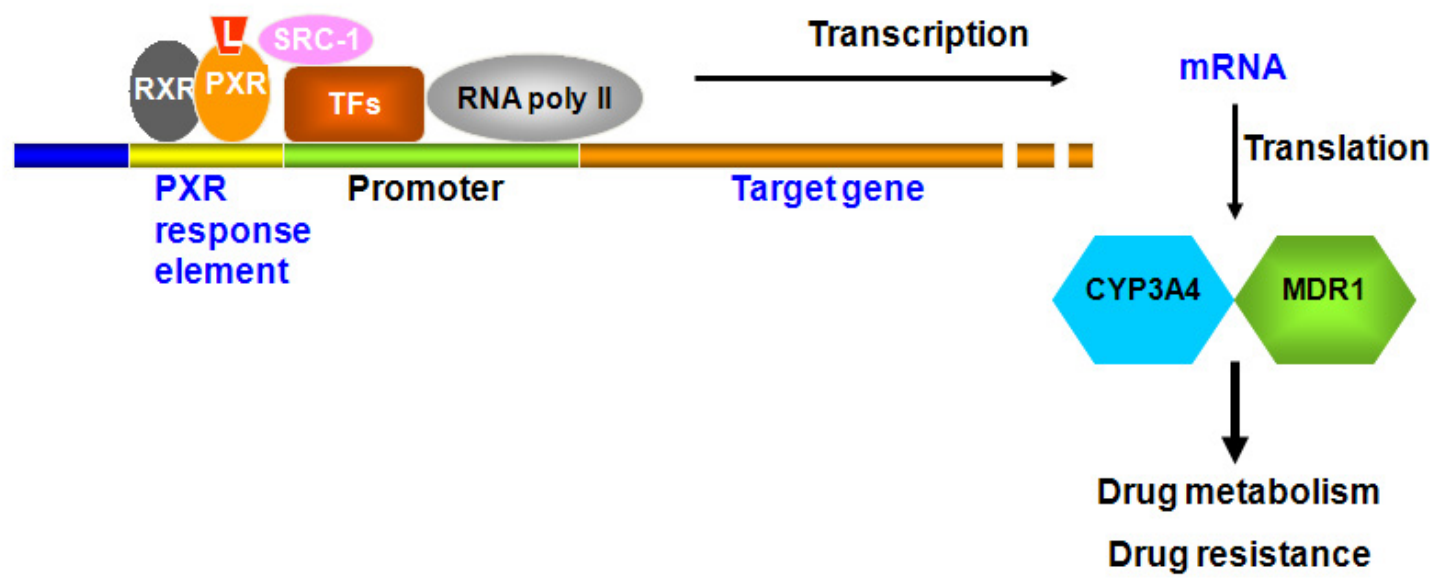

Figure 1-2. Schematic representation of hPXR function. With ligand binding, PXR dimerizes with RXR. RXR/PXR heterodimer binds to the response element of target genes, like CYP3A, CYP2B and MDR1 and regulates their transcription. 
unknown function [29].

In addition to the splice variants, genetic variations also were found in the hPXR exon coding regions. Heretofore, there are 227 SNPs have been found [26]. Among all the exons, so far exon4, encoding the C-terminal portion of the DBD and part of the Nterminal portion of the LBD, has most identified SNPs. Some SNPs such as P27S can affect protein function by either change in hydrophobicity or creation of a serine phosphorylation site $[28,30]$. The variations become further complicated when genetic variants are also found in the promoter region and other non-coding regions of hPXR. Probably, those individual variations could account for the different dynamics patterns in different patients, when identical drugs were used.

\section{PXR Antagonists}

Due to the presence of drug-drug interactions, PXR antagonists seem to be the promising small molecules that could block PXR-mediated drug-drug interactions, and optimize the efficacy of therapeutics. Designing efficient antagonists against PXR are becoming a trend in clinical medicine. Recently, PXR gene activity has been detected in endometrial cancer but not normal tissues, highlighting the oncogene-like roles of PXR in tumorigenesis. This notion is further supported by the expression of PXR in prostate cancer, breast cancer and osteosarcoma tissues, in addition to tumor cell lines [31-34]. In prostate cancer cell line PC-3 and endometrial cancer cell line HEC-1, knocking down PXR expression by RNA interference (RNAi) has been shown to be a useful approach to down-regulate CYP3A4 and MDR1. The diminishment of PXR-mediated expression of CYP3A4 and MDR1 significantly increase the therapeutic sensitivities to anticancer agents such as paclitaxel and cisplatin, with corresponding reduced drug resistance, as already perfectly reviewed [35].

So far, database of PXR antagonists is expanding. Those antagonists include but are not limited to ET-743, some polychlorinated biphenyls, ketoconazole, fluconazole, enilconazole, sulforaphane and coumestrol [36-41]. However, it is still elusive whether those antagonists, like ET-743, could directly bind to PXR or not. Additionally, ketoconazole was shown to function as a wide-range inhibitor for many nuclear receptors including PXR, by disrupting NR-co-activator interaction. In contrast, as a PXR antagonist, Sulforaphane (SFN) inhibits PXR function by directly binding to PXR [40]. Note that SFN still has PXR antagonist independent functions such as histone deacetylase inhibition and Phase II enzymes induction.

The mechanisms through which most current antagonists inhibit PXR function have been proposed. The antagonists will bind to the outer surface of PXR at the AF-2 domain and compete with PXR required co-activators [42]. Recently, computational methods have been used for discovering new antagonists [43]. Because of the promiscuity of potential PXR ligands discussed previously, it is difficult to design effective antagonists targeting the PXR ligand binding pocket. Therefore, the high-through-put screening of a huge pool of pre-generated chemical compounds seems to be a more efficient way to 
identify some specific PXR antagonists [35]. However, no specific PXR antagonist has been identified. Testing the overall effects of those antagonists on PXR functions in vivo or whether they really can improve the therapeutic efficacy will rely on the mouse models to be discussed.

\section{Crosstalk between PXR and other Nuclear Receptors}

There are 48 human nuclear receptors have been identified so far (Figure 1-3). These nuclear receptors work in concert with each other in the regulation of gene transcription. PXR and some other nuclear receptors work together and form a complex network to coordinately regulate metabolism of both xenobiotics and endobiotics, thus protecting from diverse groups of adverse chemicals [27]. There are a few types of coordination among PXR and other nuclear receptors. First, PXR functions with other nuclear receptors to regulate the same target genes. For example, FXR and PXR together can form a feedback mechanism to induce CYP3A4 gene expression which in turn can regulate bile acid metabolism, thus protecting hepatocytes from toxicity of bile acid. This is further supported by the fact that lithocholic acid (LCA) still, to some extent, can induce CYP3A4 gene expression in a PXR knockout mouse [44, 45]. Second, activities of PXR can be inhibited by target genes of other nuclear receptors. For example, small heterodimer partner (SHP) can inhibit transcriptional activity of PXR in a dose dependent manner [46]. Third, activities of PXR can be boosted by other genes. For instance, hepatocyte nuclear factor-4 alpha (HNF-4 alpha) is able to induce expression of PXR, which is further supported by the phenotypes of the HNF-4 alpha mutant mouse model [47]. In addition to the networks discussed above, PXR also interacts with Liver X Receptor (LXR), Glucocorticoid Receptor (GR), constitutive androstane Receptor (CAR) and Vitamin D Receptor (VDR) [27].

\section{PXR Mutant Mouse Models}

Due to the genomic similarities between mouse and human, mouse is a good animal model to elucidate the roles of many genes including PXR. So far, there are two kinds of PXR mutant models. Each kind has two different lines. The first kind is the PXR knockout mouse. Because the PXR-null mice are viable, fertile and have no obvious developmental deficiencies, it suggests that PXR is not essential for mouse development or physiological homeostasis $[48,49]$. However, in contrast with the PXR wild type mice, PXR-null mice are no longer responsive to PXR ligands such as PCN.

Because of the different ligand binding domain (LBD) of PXR between mouse and human, some rodent robust PXR ligands, however, are weak for human PXR, and vice versa [50]. This will preclude further probing of PXR agonist or antagonist effects using mouse models for preclinical implications. To by pass this problem, three PXR humanized mouse models were generated. Those humanized PXR mutant mice will no longer respond to the rodent-specific PXR ligand PCN. One is Alb-hPXR mice generated by cDNA in which Alb-hPXR is restricted in liver [49]. The other is a bacterial artificial 


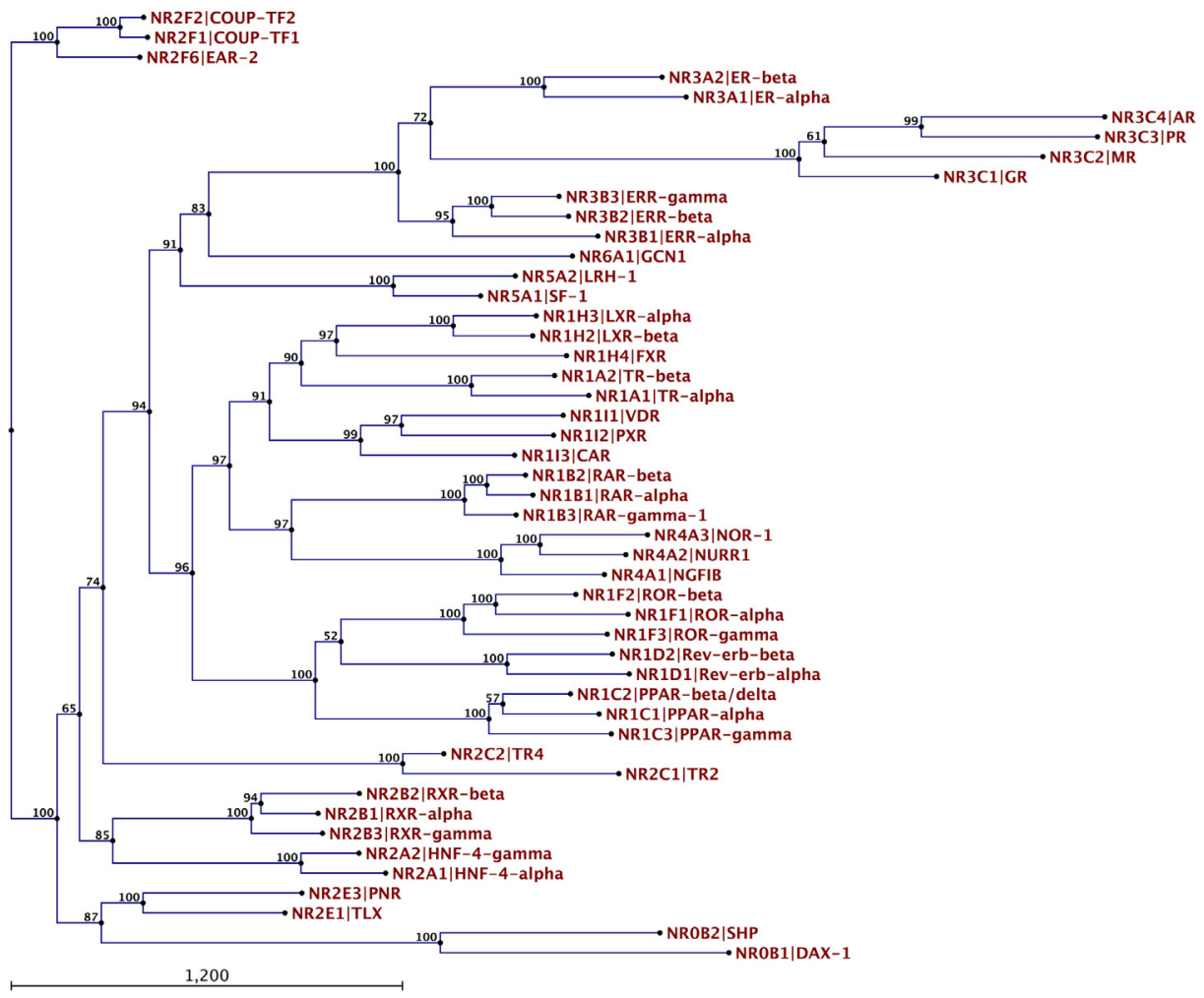

Figure 1-3. Phylogenetic tree of human nuclear receptors (from Wikipedia). There are 48 known human nuclear receptors. PXR interplays with several other nuclear receptors including CAR and VDR which belong to the same group as PXR, and those from other groups, like GR, RXR $\alpha, \mathrm{RXR} \beta, \mathrm{FXR}, \mathrm{PPAR} \gamma$ and LXR. 
chromosome (BAC) transgenic mouse line where PXR gene is under control of the endogenous human PXR promoter [51]. The third one is the mouse line where human PXR is fused to a viral VP16 coactivator, resulting in a constitutively active form of human PXR [52]. The PXR-humanized mice have been shown to be useful models to bypass the species differences in response to PXR ligands. 


\section{Chapter 2. Materials and Methods}

\section{Reagents}

Dulbecco's modified eagle medium (DMEM), phenol red-free DMEM, dialyzed FBS, Recovery ${ }^{\mathrm{TM}}$ cell culture freezing medium, non-essential amino acids (NEAA), HEPES (1 $\mathrm{M}, \mathrm{pH}$ 7.3), penicillin/streptomycin (antibiotics), sodium Pyrurate, Zeocin ${ }^{\mathrm{TM}}$, Geneticin ${ }^{\circledR}$, blasticidin, $0.05 \%$ trypsin/EDTA, GeneBLAzer ${ }^{\circledR}$ loading kit and Dulbecco's phosphate buffered saline (DPBS) without calcium and magnesium were from Invitrogen. Matrigel ${ }^{\mathrm{TM}}$ matrix was from BD Biosciences. Charcoal treated FBS was from Hyclone. Hygromicin B was from Roche. Dimethyl sulfoxide (DMSO) was form Fisher. Dexamethasone, chenodeoxycholic acid (CDCA) and GW4064 were from Sigma. Calcitriol $(1 \alpha, 25$-dihydroxyvitamin D3) was from Calbiochem. 9-cis-retinoic acid was from Biomel. Rosiglitazone was form Sequoia. TO901317 was from Cayman Chemical. Tissue culture flasks, 384 well, black-wall with clear flat bottom tissue culture treated and Poly-D-Lysine surface plates were from Corning.

\section{Equipment}

Matrix WellMate with stacker; 384-channel VPrep ${ }^{\circledR}$ pipetting station; EnVision 2102 multilabel reader; Biomek ${ }^{\circledR} \mathrm{FX}^{\mathrm{P}}$ laboratory automation workstation; 384-multichanel pipetting head; $10 \mathrm{H}$ and $50 \mathrm{H}$ pin.

\section{Cell Lines}

GR-UAS-bla HEK 293T, VDR-UAS-bla HEK 293T, RXR $\alpha$-UAS-bla HEK 293T, RXR $\beta$-UAS-bla HEK 293T, FXR-UAS-bla HEK 293T, PPAR $\gamma$-UAS-bla 293-H, LXR $\alpha-$ UAS-bla HEK 293T, LXR $\beta$-UAS-bla HEK 293T cell lines were from invitrogen. All cell lines except RXR $\alpha, \mathrm{RXR} \beta$, and FXR were maintained in Matrigel ${ }^{\mathrm{TM}}$ matrix precoated flasks in the humidified $37^{\circ} \mathrm{C} / 5 \% \mathrm{CO}_{2}$ incubator. Cell thawing, propagation and freezing were performed as described in GeneBLAzer ${ }^{\circledR}$ cell-based assay protocol.

\section{Mycoplasma Detection Assay}

MycoAlert ${ }^{\circledR}$ mycoplasma detection kit was from Lonza. At every cell passage, after cells were spun down $200 \mu \mathrm{l}$ cell culture supernatant was taken and centrifuged at $200 \mathrm{xg}$ for $5 \mathrm{~min}$. $100 \mu \mathrm{l}$ cleared supernatant was transferred into a white walled 96-well plate as test sample. $100 \mu \mathrm{l}$ of MycoAlert® reagent was added into the sample. After $5 \mathrm{~min}$ luminescence was read and data was recorded as A. Then $100 \mu \mathrm{l}$ of MycoAlert ${ }^{\circledR}$ substrate was added into the well. After 10 min luminescence was read again and data was recorded as $\mathrm{B}$. B/A ratio was calculated. If $\mathrm{B} / \mathrm{A}<1$, then it's negative, otherwise it is positive (mycoplasma contaminated). 


\section{Beta-lactamase Reporter Assay}

Assays were performed as described below in the antagonist assay section. After subtracting the average fluorescence intensity of both $460 \mathrm{~nm}$ and $530 \mathrm{~nm}$ emission from the cell-free control wells, the $460 \mathrm{~nm} / 530 \mathrm{~nm}$ ratio was calculated. For $\mathrm{EC}_{50}$ determination, the ratios were plotted against primary agonist concentration in log scale and then analyzed using Prism software (GraphPad Software, Inc., San Diego, CA) Sigmoidal dose-response equation with varying slope was used to fit the data and generate $\mathrm{EC}_{50}$ value. For compound assay, the percentage of inhibition activity is calculated as inhibition activity $=1$ - (test compound-negative control)/(positive control negative control)*100\%. The percentage of inhibition activity is plotted against test compound concentration in log scale using Prism one site competition. Z' factor was calculated for each assay plate using $Z^{\prime}$ factor $=1-\left[\left(3 * \mathrm{SD}_{\text {pos. }}+3 * \mathrm{SD}_{\text {neg. }}\right) /\left(\operatorname{avg}_{\text {pos. }}-\operatorname{avg}_{\text {neg. }}\right)\right]$. The assays having $Z$ ' factor of above 0.5 will be accepted.

\section{Compound Profiling}

Compounds were initially dissolved in DMSO $(10 \mathrm{mM}) .384-w e l l$ master dilution plates were made by serially one to three diluting across the plate, starting at $10 \mathrm{mM}$ to $0.508 \mu \mathrm{M}$ in DMSO. 384-multichanel pipetting head with $10 \mathrm{H}$ or $50 \mathrm{H}$ Pins were used to transfer compound from the master dilution plate to assay plates by Biomek ${ }^{\circledR} \mathrm{FX}^{\mathrm{P}}$ laboratory automation workstation. $10 \mathrm{H}$ pin carries $25 \mathrm{nl}$ liquid and $50 \mathrm{H}$ pin carries $50 \mathrm{nl}$ for each transfer.

\section{Antagonist Assay}

Cells were harvested at $80 \%$ confluence and then re-suspended in assay medium as described in chapter 3. Certain concentrations of the cell suspension was dispensed into 384-well, black-wall, clear bottom assay plates. Plates were centrifuged at $1000 \mathrm{rpm}$ for 1 minute to help cells attach to the bottom. After $30 \mathrm{~min}$, test compounds were transferred into to the plates using Biomek ${ }^{\circledR} \mathrm{FX}^{\mathrm{P}}$ laboratory automation workstation. The primary agonist was applied to stimulate cells after test compounds were transferred. DMSO was used as a negative control of compound treatment. The primary agonist was used as a positive control of compound treatment. Plates were then incubated in the humidified $37^{\circ} \mathrm{C} / 5 \% \mathrm{CO}_{2}$ incubator for 16 hours. LiveBLAzer substrate was loaded after plates were cooled down to room temperature. After certain time incubation in the dark the plates were read on EnVision 2102 multilabel reader for fluorescence intensity at $460 \mathrm{~nm}$ and $530 \mathrm{~nm}$. 


\section{Chapter 3. Determing the Specificity of hPXR Antagonists}

\section{Introduction}

Of the 48 human nuclear receptors identified so far, several of them have been demonstrated to interplay with PXR. The expression of PXR target gene thus is controlled by many physiopathological parameters other than the transcriptional activity of PXR. The nuclear receptors involved in functional crosstalk with PXR are glucocorticoid receptor (GR), retinoid X receptor (RXR), farnesoid X receptor (FXR), peroxisome proliferators-activated receptor (PPAR), liver X receptor (LXR). In addition, vitamin $\mathrm{D}$ receptor (VDR) and constitutive androstane receptor (CAR) belong to the same subfamily of NR as PXR and share many common features with PXR. They are also involved in the signaling pathway of PXR target gene regulation.

Because of the interplay between PXR and these nuclear receptors they share many modulators. Many antagonists of these nuclear receptors have been identified so far. However, most of them are not specific. When a drug is administrated to antagonize one nuclear receptor it often affects the activity of other nuclear receptors involved in other signaling pathways as well. So, to identify specific antagonists for PXR is extremely important in both clinical and basic research.

A panel of nuclear receptor cellular assays have been built by Invitrogen through stably engineering expression of a fusion protein consisting of the target nuclear receptor ligand binding domain (LBD) and Gal4 DNA binding domain (DBD) in a parental HEK 293 cell line containing the beta-lactamase reporter gene under transcriptional control of an upstream activation sequence (UAS) (Figure 3-1). This reporter gene assay is able to detect the functional response of a ligand or modulator would have on its receptor. Compared with the traditional cell-based reporter gene assay which uses endogenous or exogenous full-length receptors, GeneBLAzer eliminates the limitation of selectivity because different nuclear receptors can bind to the same or similar response elements and ligands [53].

In this assay when the ligand binds to the LBD of nuclear receptor the fusion protein will bind to the UAS through the DBD of Gal4. This process will activate the transcription of beta-lactamase, which will be expressed and secreted into the cytoplasm. The protein expression level would be measured by reading the fluorescence intensity of a fluorescent substrate which could be dissected by beta-lactamase. When excited the substrate emits green light if it's intact, blue light if it's been cleaved (Figure 3-2).

In my experiment eight of the GeneBLAzer cell lines engineered with nuclear receptors most functionally related to PXR were used to study the specificity of 92 previously identified PXR antagonists. These cell lines are GR-UAS-bla HEK 293T, VDR-UAS-bla HEK 293T, RXR $\alpha$-UAS-bla HEK 293T, RXR $\beta$-UAS-bla HEK 293T, FXR-UAS-bla HEK 293 T, PPAR $\gamma$-UAS-bla 293-H, LXR $\alpha$-UAS-bla HEK 293 T, LXR $\beta-$ UAS-bla HEK 293T cells. 


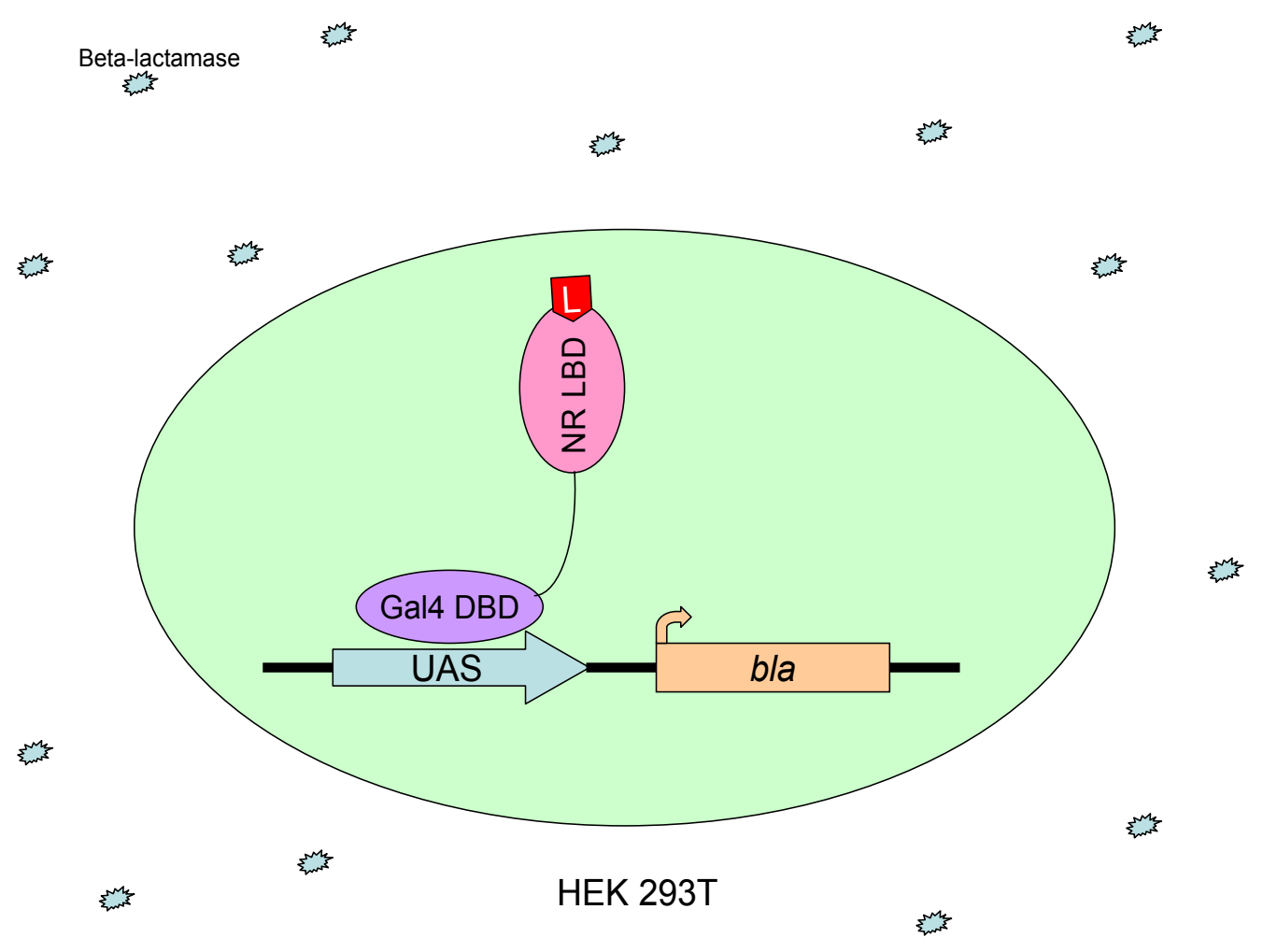

Figure 3-1. Schematic representation of GeneBLAzer nuclear receptor cell lines. The cell stably expresses a fusion protein consisting of the target nuclear receptor ligand binding domain (LBD) and Gal4 DNA binding domain (DBD). The fusion protein will regulate the expression of beta-lactamase reporter gene which is under the control of an UAS response element. When a ligand binds to the LBD of target nuclear receptor betalactamase will express and excrete out of the cell. 

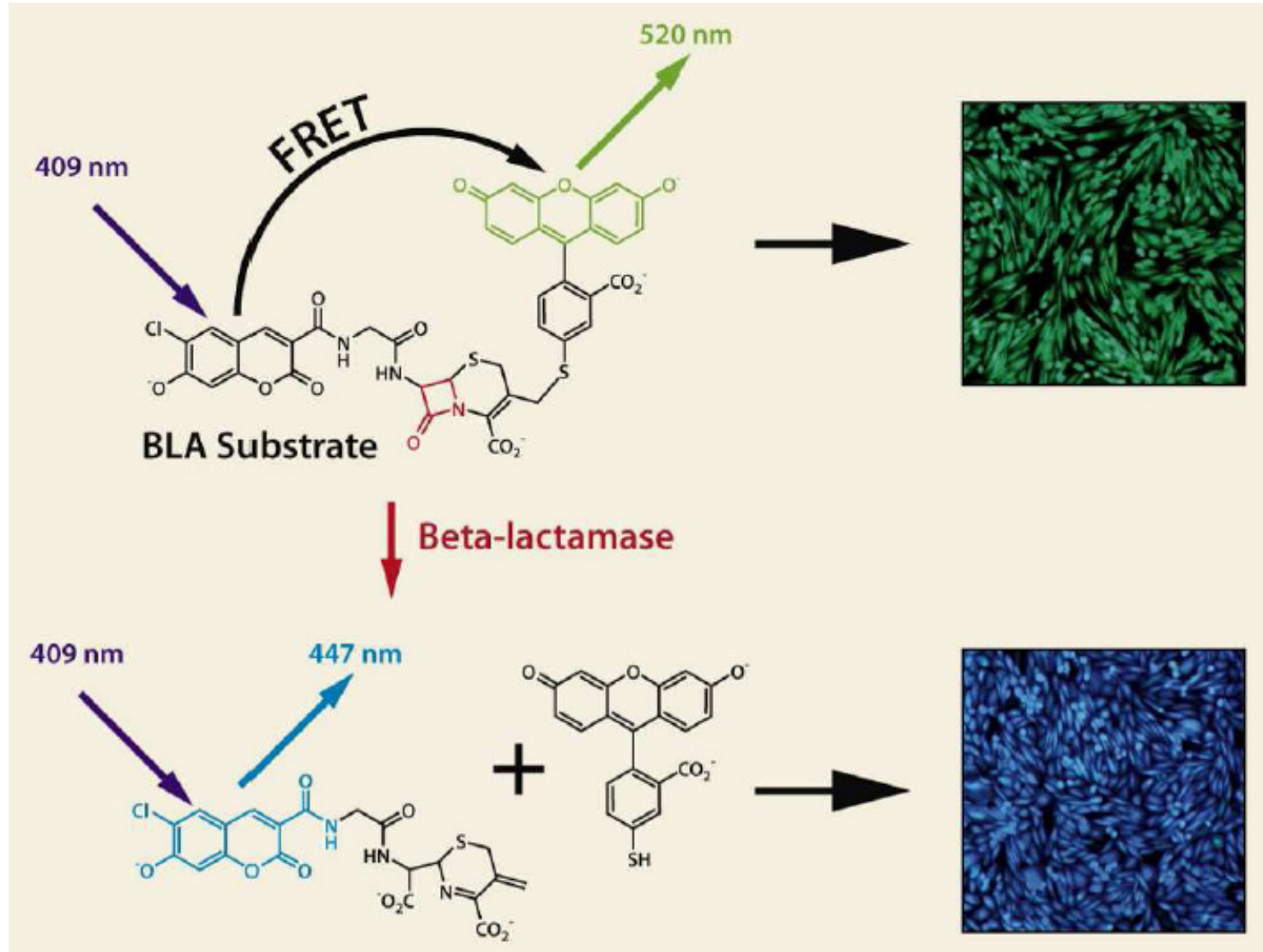

Figure 3-2. Schematic illustration of FRET assay (Invitrogen protocol). The BLA substrate has two fluoroprobes, coumarin and fluorescein. In the absence of bla expression in the cell, the substrate remains intact and is capable of fluorescence resonance energy transfer (FRET) and emission of green light. In the presence of bla expression, the substrate is cleaved and FRET is disrupted resulting in emission of blue light. 


\section{Materials and Methods}

\section{Cell Culture}

GR was cultured in DMEM supplemented with 10\% dialyzed FBS, 0.1 mM NEAA, 25 mM HEPES ( $\mathrm{pH} 7.3$ ), $100 \mathrm{U} / \mathrm{ml}$ penicillin, $100 \mu \mathrm{g} / \mathrm{ml}$ streptomycin, $150 \mu \mathrm{g} / \mathrm{ml}$ hygromycin B and $80 \mu \mathrm{g} / \mathrm{ml}$ Zeocin. VDR was cultured in DMEM supplemented with 10\% dialyzed FBS, $0.1 \mathrm{mM}$ NEAA, $25 \mathrm{mM}$ HEPES (pH 7.3), $100 \mathrm{U} / \mathrm{ml}$ penicillin, 100 $\mu \mathrm{g} / \mathrm{ml}$ streptomycin, $80 \mu \mathrm{g} / \mathrm{ml}$ hygromycin and $80 \mu \mathrm{g} / \mathrm{ml}$ Zeocin. RXR $\alpha$ and RXR $\beta$ were cultured in DMEM supplemented with 10\% dialyzed FBS, $0.1 \mathrm{mM}$ NEAA, $25 \mathrm{mM}$ HEPES (pH 7.3), $100 \mathrm{U} / \mathrm{ml}$ penicillin, $100 \mu \mathrm{g} / \mathrm{ml}$ streptomycin, $100 \mu \mathrm{g} / \mathrm{ml}$ hygromycin and $100 \mu \mathrm{g} / \mathrm{ml}$ Zeocin; FXR was cultured in DMEM supplemented with $10 \%$ dialyzed FBS, $0.1 \mathrm{mM}$ NEAA, $25 \mathrm{mM}$ HEPES (pH 7.3), $100 \mathrm{U} / \mathrm{ml}$ penicillin, $100 \mu \mathrm{g} / \mathrm{ml}$ streptomycin, $100 \mu \mathrm{g} / \mathrm{ml}$ hygromycin and $100 \mu \mathrm{g} / \mathrm{ml}$ Zeocin. PPAR $\gamma$ was cultured in DMEM supplemented with 10\% dialyzed FBS, 0.1 mM NEAA, 25 mM HEPES (pH 7.3), $100 \mathrm{U} / \mathrm{ml}$ penicillin, $100 \mu \mathrm{g} / \mathrm{ml}$ streptomycin, $100 \mu \mathrm{g} / \mathrm{ml}$ hygromycin, $500 \mu \mathrm{g} / \mathrm{ml}$ Geneticin and $1 \mathrm{mM}$ sodium pyrurate. LXR $\alpha$ was cultured in DMEM supplemented with 10\% dialyzed FBS, $0.1 \mathrm{mM}$ NEAA, $25 \mathrm{mM}$ HEPES (pH 7.3), $100 \mathrm{U} / \mathrm{ml}$ penicillin, 100 $\mu \mathrm{g} / \mathrm{ml}$ streptomycin, $80 \mu \mathrm{g} / \mathrm{ml}$ hygromycin and $80 \mu \mathrm{g} / \mathrm{ml}$ Zeocin. LXR $\beta$ was cultured in DMEM supplemented with 10\% dialyzed FBS, 0.1 mM NEAA, 25 mM HEPES (pH 7.3), $100 \mathrm{U} / \mathrm{ml}$ penicillin, $100 \mu \mathrm{g} / \mathrm{ml}$ streptomycin, $80 \mu \mathrm{g} / \mathrm{ml}$ hygromycin and $15 \mu \mathrm{g} / \mathrm{ml}$ blasticidin.

All cells were maintained between 5\% and 95\% confluence. Flasks for culturing GR, VDR, PPAR $\gamma$, LXR $\beta$ were coated with $1 X$ Matrigel $^{\mathrm{TM}}$ matrix and incubated for 15 min before plating.

For any assay process, cells were maintained in assay medium. GR cells were harvested and re-suspended in 98\% phenol red-free DMEM containing 2\% charcoal stripped FBS, $0.1 \mathrm{mM}$ NEAA, $25 \mathrm{mM}$ HEPES (pH 7.3), $100 \mathrm{U} / \mathrm{ml}$ penicillin, $100 \mu \mathrm{g} / \mathrm{ml}$ streptomycin, $1 \mathrm{mM}$ sodium pyrurate. PPAR $\gamma$ cells were maintained in $99 \%$ phenol redfree DMEM with 1\% charcoal stripped FBS, $100 \mathrm{U} / \mathrm{ml}$ penicillin and $100 \mu \mathrm{g} / \mathrm{ml}$ streptomycin. VDR, RXR $\alpha, \mathrm{RXR} \beta, \mathrm{FXR}, \mathrm{LXR} \alpha$ and $\mathrm{LXR} \beta$ cells were maintained in $98 \%$ phenol red-free DMEM with 2\% charcoal stripped FBS, $0.1 \mathrm{mM} \mathrm{NEAA,} 100 \mathrm{U} / \mathrm{ml}$ penicillin, $100 \mu \mathrm{g} / \mathrm{ml}$ streptomycin, and $1 \mathrm{mM}$ sodium pyrurate.

\section{Assay Optimization}

All cells were tested negative for mycoplasma. Cells were resuspended in assay medium for any assays. Four different concentrations of cells were plated. For GR and VDR the cell number was 10k, 20k, 30k and 40k, for RXR $\alpha$ and RXR $\beta$ the cell number was $5 \mathrm{k}, 10 \mathrm{k}, 20 \mathrm{k}$ and $30 \mathrm{k}$ per well. Cells were stimulated with maximum concentration of their primary agonist. Plates were incubated at $37^{\circ} \mathrm{C} / 5 \% \mathrm{CO}_{2}$. After plates were cooled down to room temperature different concentration of substrates were loaded. Plates were 
read for fluorescence intensity at interval times. Response ratio is calculated using the $460 \mathrm{~nm} / 530 \mathrm{~nm}$ ratio of the stimulated wells divided by the unstimulated wells. A bar graph was created using Response ratio against different assay conditions.

\section{Agonist Dose-response}

Ten different concentrations of agonist dilution were made by serially diluting across the plate, starting at the maximum concentration for stimulation (Invitrogen validation summary) decreasing in one third in $100 \%$ DMSO. Cells were seeded at the number per well as determined in the section on assay optimization. The $10 \mathrm{H}$ pin tool which carries $25 \mathrm{nl}$ liquid was used to transfer the agonist into the cell plates. Plates were incubated for 16 hours. Substrate was loaded and the plates were read at the condition determined as described in the section on assay optimization. $460 \mathrm{~nm} / 530 \mathrm{~nm}$ ratios for each well were calculated, plotted and $\mathrm{EC}_{50}$ was determined as described in chapter two.

\section{Compound Assay}

Cells (with concentration determined in optimization) were dispensed by WellMate at medium speed. Plates were centrifuged at $1000 \mathrm{rpm}$ for $1 \mathrm{~min}$ to spin down the cells. The $50 \mathrm{H}$ pin tool was used to transfer from the compounds plate into the cell plates twice $(100 \mathrm{nl}$ in total). Then agonist plate was transferred once $(50 \mathrm{nl})$. Plates were incubated for 16 hours. Substrate was loaded. Plates were read after the incubation time determined in assay optimization. Data was analyzed as described in chapter two.

\section{Results and Discussion}

\section{Assay Performance under Variable Conditions}

To optimize the conditions, assays should be performed under different conditions including cell numbers, compounds treatment time, DMSO concentration, and substrate concentration, loading time and incubation time, plate types. According to the validation data from the manufacturer all the cell lines performed the best for 16 hours incubation after compounds were added. We used the same incubation time in our assay. Our assay was performed in 384-well black wall, clear bottom plates with $25 \mu$ assay volume and $6 \mathrm{X}$ substrate $(5 \mu \mathrm{l})$ loading. Our system allowed us to use $50 \mathrm{H}$ pin which carries $50 \mathrm{nl}$ of liquid transferring twice from the stock into the $25 \mu \mathrm{l}$ cells, which made the final DMSO concentration $0.6 \%$. According to the validation data provided by Invitrogen, it doesn't affect the assay performance when DMSO is below $1 \%$.

In order to distinguish the compounds which can inhibit the activation of the transcriptional activity of the nuclear receptor by its primary agonist from those that can't inhibit it, it is important to find the condition under which the signals generated by 
unstimulated wells (neg. control) and stimulated wells (pos. control) are different enough that any minor effect on the transactivity will be observable. That is to say the higher response ratio (pos. controlneg. control) the better.

Among the eight cell lines tested, GR had the highest response ratio of 15 to 22 . The signal produced by each well is quite consistent. The other three cell lines, VDR, FXR and LXR $\alpha$ had a moderate response ratio of about 10 to 15 . The signal varied especially for FXR and LXR $\alpha$. The response ratio of the other four cell lines, RXR $\alpha, R X R \beta, \operatorname{PPAR} \gamma$ and LXR $\beta$ was relatively low, at around 5 (Figure 3-3). This means that GR is a cell line that can generate repeatable results and distinguish compounds that have minor differences on inhibition activity. $\operatorname{RXR} \alpha, \operatorname{RXR} \beta, \operatorname{PPAR} \gamma$ and $\operatorname{LXR} \beta$ give the poorest performance on the assay.

The cell number is an important condition needed to be determined for our assay. When cells were too few, a small amount of beta-lactamase would be produced in each well. The signal generated would be relatively low after subtracting the basal signal (cellfree wells), and it would be more sensitive to background signal and thus produce a big error bar. When cells seeded in each well are too many they would reach confluence after 16 hours incubation which would affect the health of cells and the performance of the assay. With the lowest number of cells seeded in each well the highest response ratio was generated with the biggest error bars (Figure 3-3). When the cell number increased the response ratio decreased a little but with lower error bars. Images were taken after 16 hours incubation show that the cells were already confluent for the wells that seeded $30 \mathrm{k}$ cells. We finally choose to use 20k cells per well for GR, VDR, FXR and PPAR $\gamma, 10 \mathrm{k}$ cells per well for $\operatorname{RXR} \alpha, \operatorname{RXR} \beta, \operatorname{LXR} \alpha$ and $\operatorname{LXR} \beta$ for the following assays because at this density cells would not reach confluence in the plates and gave relatively higher positive to negative window with lower error bars.

To determine the best substrate incubation time for this assay, plates were read at interval times after loading substrate (Figure 3-3). The response ratio window was increasing after substrate was loaded until after two hours. The signal window remained stable for at least 5 hours for GR, RXR $\alpha, \operatorname{RXR} \beta, \operatorname{LXR} \alpha$ and LXR $\beta$. For VDR the signal remained for 3 hours, while for FXR and PPAR $\gamma$ the signal window started to decrease after 2 hours. This means we could read the data in this time range that the signal window reached highest value and remained stable after substrate were loaded. We finally chose the substrate loading time of 1 hour for PPAR $\gamma, 1.5$ hours for VDR, RXR $\alpha$ and RXR $\beta, 2$ hours for GR, FXR, LXR $\alpha$ and LXR $\beta$ in the following assay.

Since this assay will read the fluorescence intensity, we have to use the black wall, clear-bottom plates for seeding the cells. However, HEK 293 cell is not easy to attach on normal plates. Poly-D-Lysine coated plates which helped the cells to attach could be used for the assay instead. It is necessary to test whether Poly-D-Lysine would have any negative affect on cell growth and assay performance before Poly-D-Lysine plates were used in the compound assay. The assay performance in both kinds of plates was tested to generate the best condition for each cell line in the assay. Under the optimized conditions generated (cell number and substrate loading time) in the previous sections, assays with 

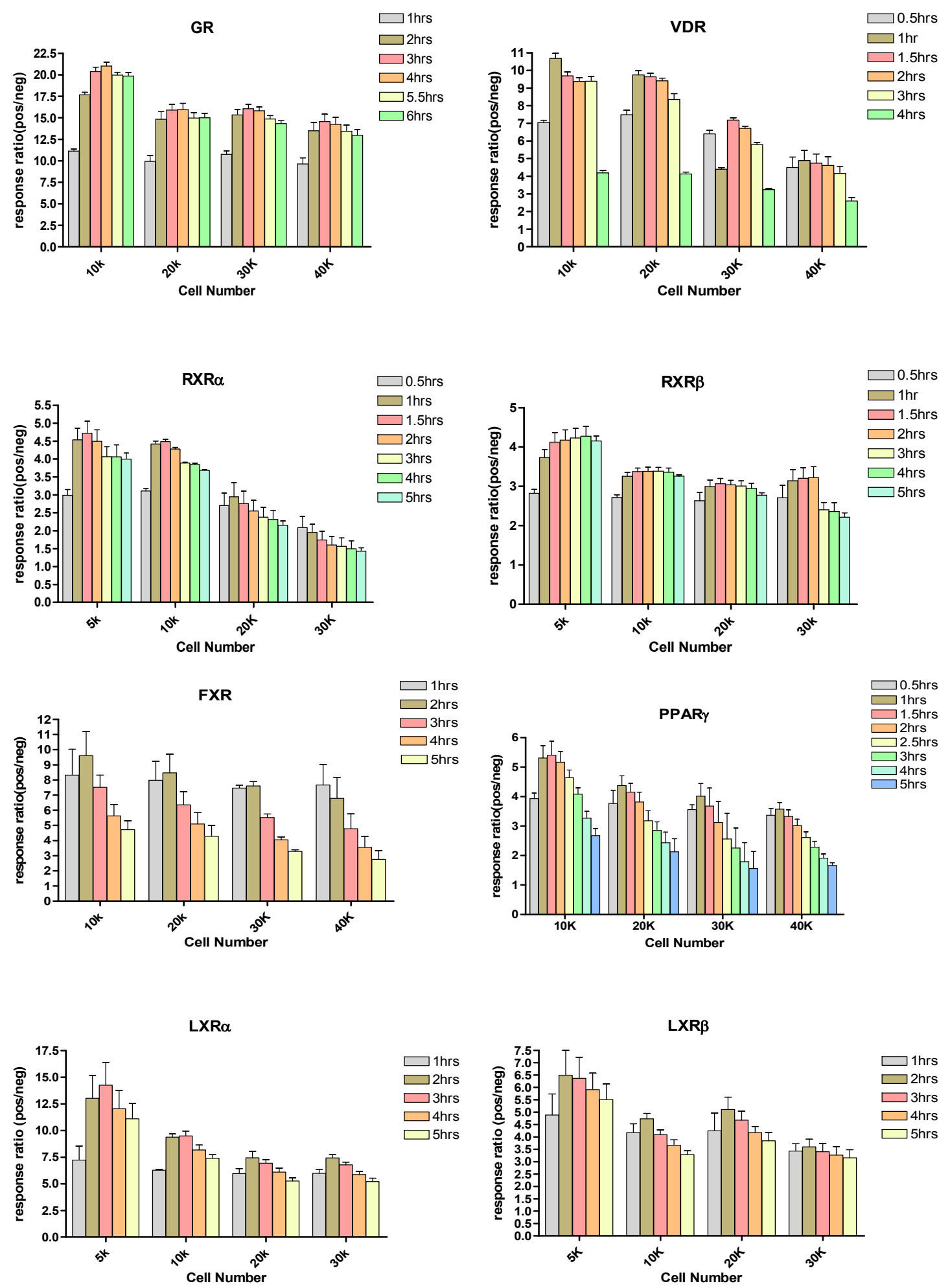

Figure 3-3. Assay performance with different cell density and substrate loading time. Response ratio (pos/neg) generated by certain cell numbers at certain time after substrate loaded. The error bars stand for \pm s.d. 
each cell line were performed in both regular plates and Poly-D-Lysine coated plates. The Z' factor which is a statistical parameter measures the quality of a particular assay in high-throughput screening showed that all the cell lines perform better in Poly-D-Lysine plates except RXR $\beta$ because it generated a very high $460 \mathrm{~nm} / 530 \mathrm{~nm}$ ratio for unstimulated wells (cells with DMSO only) (Table 3-1). The images taken after 16 hours incubation showed that cells grew as healthy as in regular plates and even denser in PolyD-Lysine coating plates than the regular plates even though the cell density is the same when seeded (supplementary Figure A-1). However, the pin would damage the coating if it touched the bottom when transferring compounds. Cells couldn't grow on the coating damaged area. Fortunately, the readout was not affected by those tiny damaged coating areas of the plates. So, Poly-D-Lysine coating plates would be used to screen the compounds for GR, VDR, RXR $\alpha, F X R, \operatorname{PPAR} \gamma, \mathrm{LXR} \alpha$ and $\mathrm{LXR} \beta$ while regular noncoating plates would be used for RXR $\beta$.

The tool used to dispense cells in the 384-well plates was also very important to generate stable and acceptable assay results. This is because the amount of expressed beta-lactamase in each well is dependent on the amount of cells seeded in each well. 384channel VPrep ${ }^{\circledR}$ pipette and Matix WellMate at 3 different dispense speeds were tested for seeding equal amounts of HEK 293T cells. It turned out that WellMate at middle speed can dispense cells equally and evenly in each well (data not shown). 16-well automatic hand pipette was used to load substrate. HEK 293T cells are notorious for not sticking well on plates. The mechanical force generated when using WellMate or VPrep dispensing the substrate would destroy the even distribution of cells which results in inconsistent reading of fluorescence intensity.

\section{$E C_{50}$ Determination}

$\mathrm{EC}_{50}$ of the agonist is variable in a small range with different experimental conditions. We tested the $\mathrm{EC}_{50}$ of the agonist for each nuclear receptor in our experiment under the optimized condition for our compound assays. The agonists used are Dexamethasone for GR, Calcitriol (1 $\alpha, 25$-dihydroxyvitamin D3) for VDR, 9-cis-retinoic acid for RXR $\alpha$ and RXR $\beta$, GW4064 for FXR, Rosiglitazone for PPAR $\gamma$, TO901317 for LXR $\alpha$ and LXR $\beta$. All these agonists were the most potent for its target among the reported agonists.

The agonists used in this assay were recommended by Invitrogen except GW4064. Another agonist for FXR, Chenodeoxycholic acid (CDCA) was used first for a dose response experiment. It turns out that at the reported maximum concentration of stimulation, the transactivity of FXR couldn't be saturated. After increased the concentration applied it showed cytotoxicity to the cell line (supplementary Figure A-2). When GW4064 was applied to stimulate FXR, a perfect dose-response curve was generated.

After graphing the dose-response curve, the $\mathrm{EC}_{50}$ was determined (Figure 3-4). They were $1.09 \mathrm{nM}$ of Dexamethasone for GR, $0.23 \mathrm{nM}$ of Calcitriol for VDR, $15.7 \mathrm{nM}$ and $16.48 \mathrm{nM}$ of 9-cis-retinoic acid for RXR $\alpha$ and RXR $\beta$ respectively, $40.05 \mathrm{nM}$ of GW4064 
Table 3-1. Z' factor of assay in regular and Poly-D-Lysine plates for each cell line.

\begin{tabular}{ccccccccc}
\hline & GR & VDR & RXR $\alpha$ & RXR $\beta$ & FXR & PPAR $\gamma$ & LXR $\alpha$ & LXR $\beta$ \\
\hline regular & 0.73 & 0.54 & 0.74 & 0.76 & 0.82 & 0.53 & 0.85 & 0.73 \\
P-D-L & 0.90 & 0.88 & 0.75 & 0.53 & 0.81 & 0.74 & 0.88 & 0.84 \\
\hline
\end{tabular}



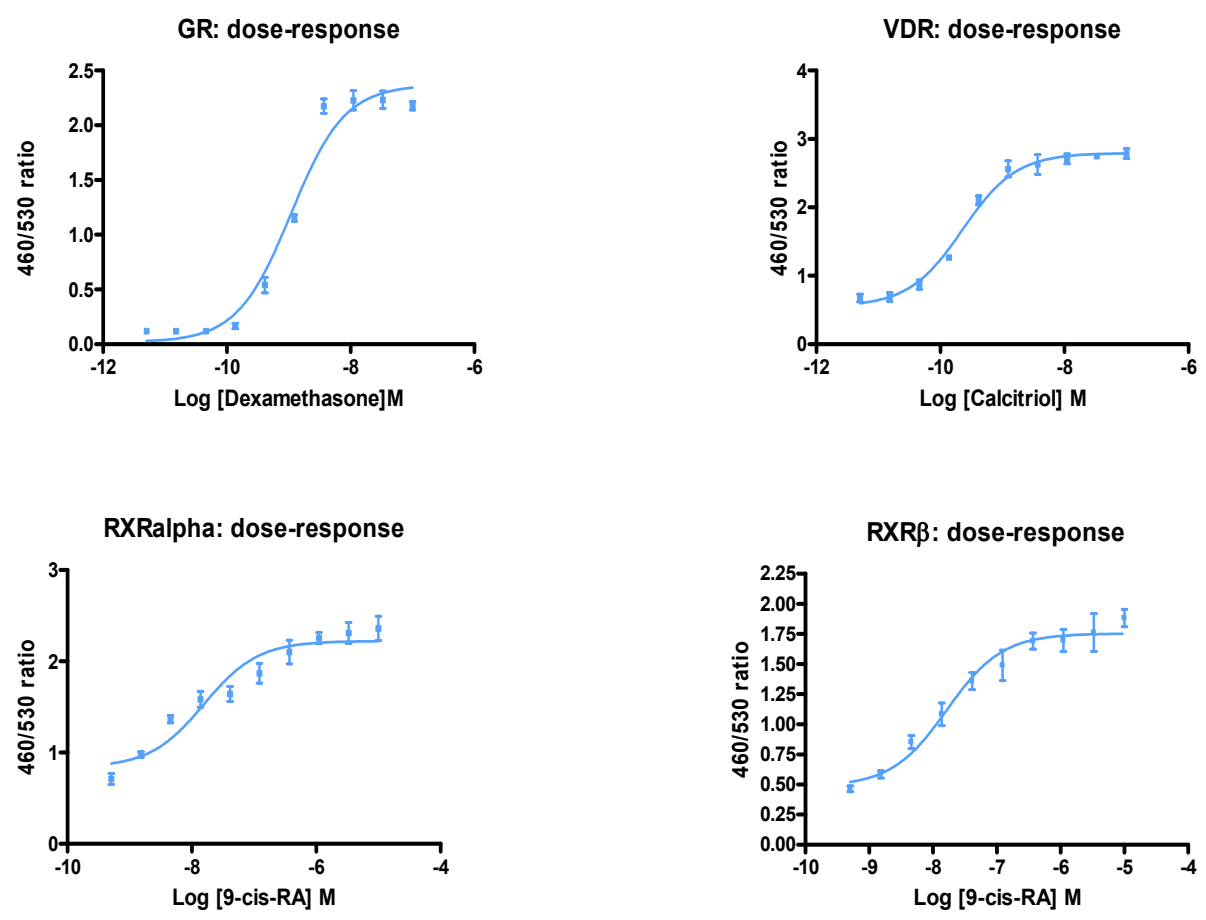

FXR: dose-response

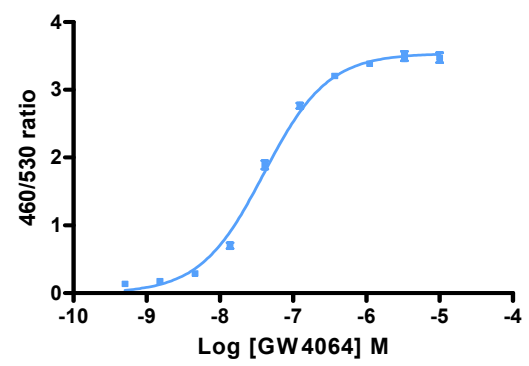

PPAR : dose - response

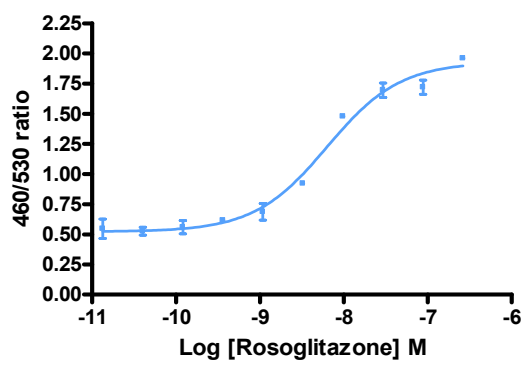

LXR $\alpha$ : dose - response

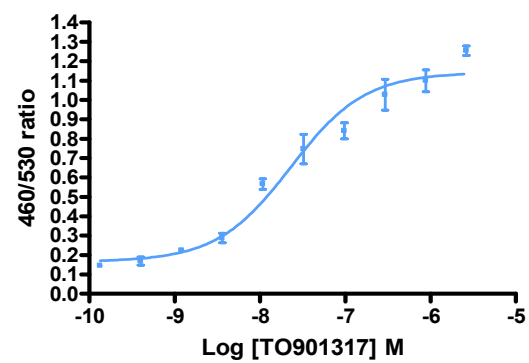

LXRß: dose - response

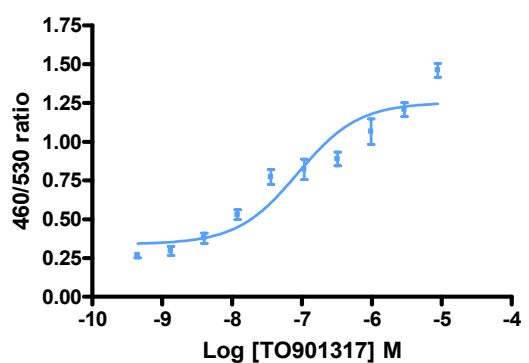

Figure 3-4. Dose response of the nuclear receptor to its primary agonist. The $\mathrm{EC}_{50}$ generated in dose-response were $1.09 \mathrm{nM}$ of Dexamethasone for GR, $0.23 \mathrm{nM}$ of Calcitriol for VDR, $15.7 \mathrm{nM}$ and $16.48 \mathrm{nM}$ of , 9-cis-retinoic acid for RXR $\alpha$ and RXR $\beta$ respectively, $40.05 \mathrm{nM}$ of GW4064 for FXR, $6.32 \mathrm{nM}$ of Rosiglitazone for PPAR $\gamma, 23.04$ $\mathrm{nM}$ and $87.52 \mathrm{nM}$ of TO901317 for LXR $\alpha$ and LXR $\beta$ respectively. The error bars stand for \pm s. d. 
for FXR, $6.32 \mathrm{nM}$ of Rosiglitazone for PPAR $\gamma, 23.04 \mathrm{nM}$ and $87.52 \mathrm{nM}$ of TO901317 for LXR $\alpha$ and LXR $\beta$ respectively. They were consistent with the reported data. With the generated dose-response curve, $\mathrm{EC}_{80}$ could also be determined. A final concentration between $\mathrm{EC}_{50}$ and $\mathrm{EC}_{80}$ was used to stimulate the nuclear receptor during the compound assay because any inhibition on the agonist induced transactivity in the range between $\mathrm{EC}_{50}$ and $\mathrm{EC}_{80}$ will be detected.

\section{Selecting Specific Compounds}

92 compounds identified as PXR antagonists without cytotoxicity in HepG cells (Wenwei Lin, unpublished data) were applied for this beta-lactamase reporter gene assay under optimized conditions for specificity using cell lines carrying GR, VDR, RXR $\alpha$, RXR $\beta, F X R$, PPAR $\gamma, L X R \alpha$ and LXR $\beta$ respectively.

Z' factor was calculated for each plate in the compounds assay (Figure 3-5). The Z' value showed that all of them are greater than 0.6 , which means the assay results are acceptable. Z' values for GR and VDR are around 0.9 and quite stable among each assay plate. This result is consistent with the one in the section on assay optimization (Figure 3-3). Both of them indicate that among the eight cell lines GR and VDR are the ones that can generate most reliable results.

The assay showed that at very low concentration all compounds don't have any inhibition activity on the transcriptional activity of the eight nuclear receptors (data not shown). However, these compounds are very potent to PXR (Wenwei Lin, unpublished data). This means when administrating at a low concentration, all compounds are relatively specific to PXR.

Among these compounds 21 hits were selected as specific PXR antagonists (Table 3-2). These compounds, such as SJ000129508, SJ000168394, SJ000200343, SJ000254150 etc, didn't show any inhibition activity for eight nuclear receptors (inhibition activity below $20 \%$ at $40 \mu \mathrm{M}$ ) but were potent inhibitors for PXR (Figure 3-6). With a large concentration range, they are specific inhibitors exclusively for PXR. We may perform SAR study to identify the structure similarity for these selected PXR antagonists in the future. Furthermore, the molecular mechanism of these antagonists to PXR needs to be unraveled by using animal models.

There are two compounds, SJ000025162 and SJ000302340 which showed inhibition activity to all the 8 cell lines. However, we were not sure whether the inhibition activity is due to its real antagonistic effect to the transcriptional activity of the nuclear receptors or the cytotoxicity to the cell lines since we noticed the cells of some wells were very sick even dead after 16 hours incubation with compounds administrated (Figure 3-7). To test if these compounds were toxic to the cells, cytotoxicity assay was performed on HEK $293 \mathrm{~T}$ cell line 24 hours incubation (Wenwei Lin, unpublished data). When SJ000302340 showed inhibition activity to the nuclear receptors it showed cytotoxicity to HEK 293T cells as well. This suggested that whether the compound was antagonist for the nuclear 

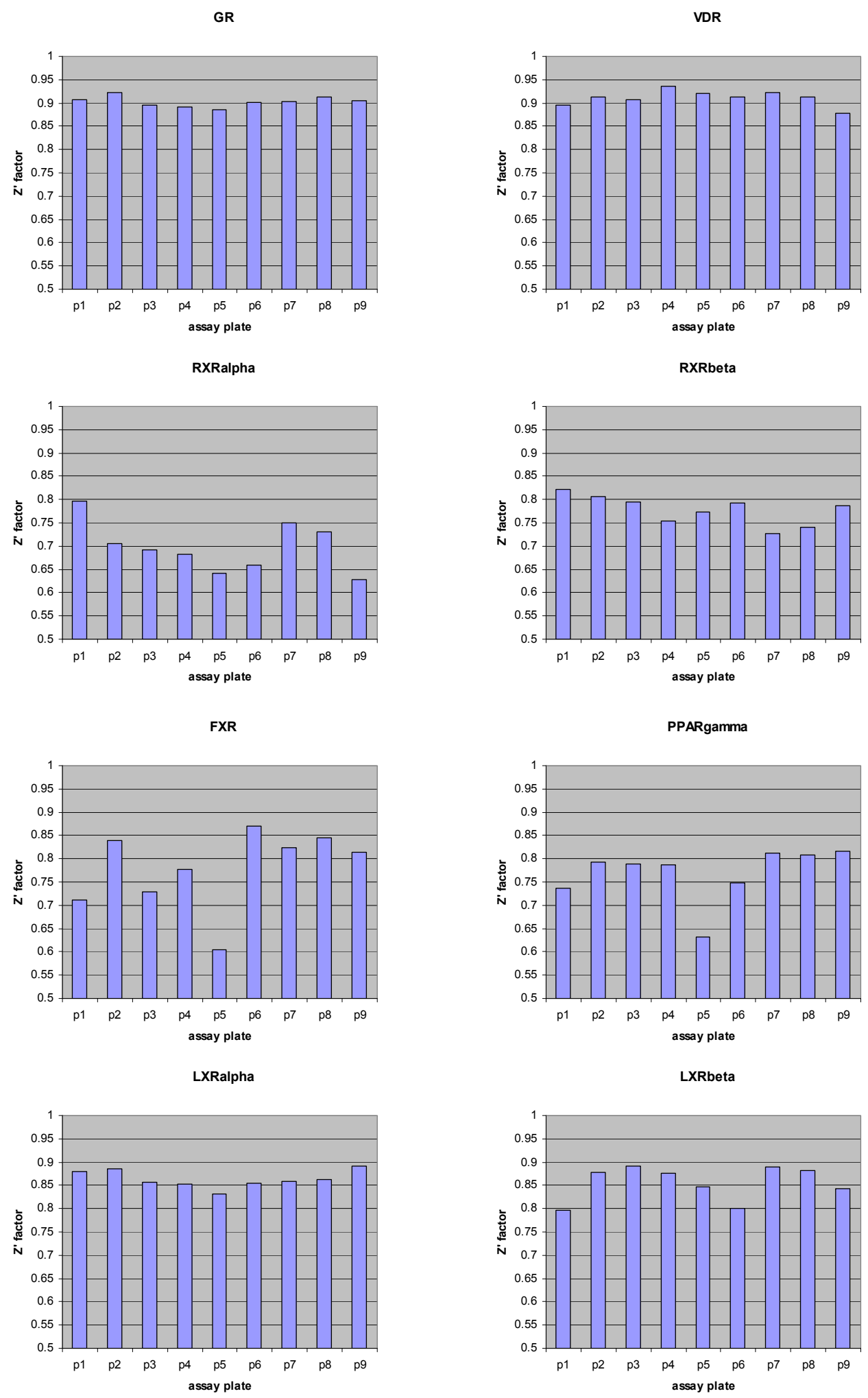

Figure 3-5. Z' factor of each assay plate. Compound assays were performed in triplicate. 92 compounds distributed in 3 master solution plates were tested. 
Table 3-2. The antagonistic effect of putative hPXR antagonists on various nuclear receptors.

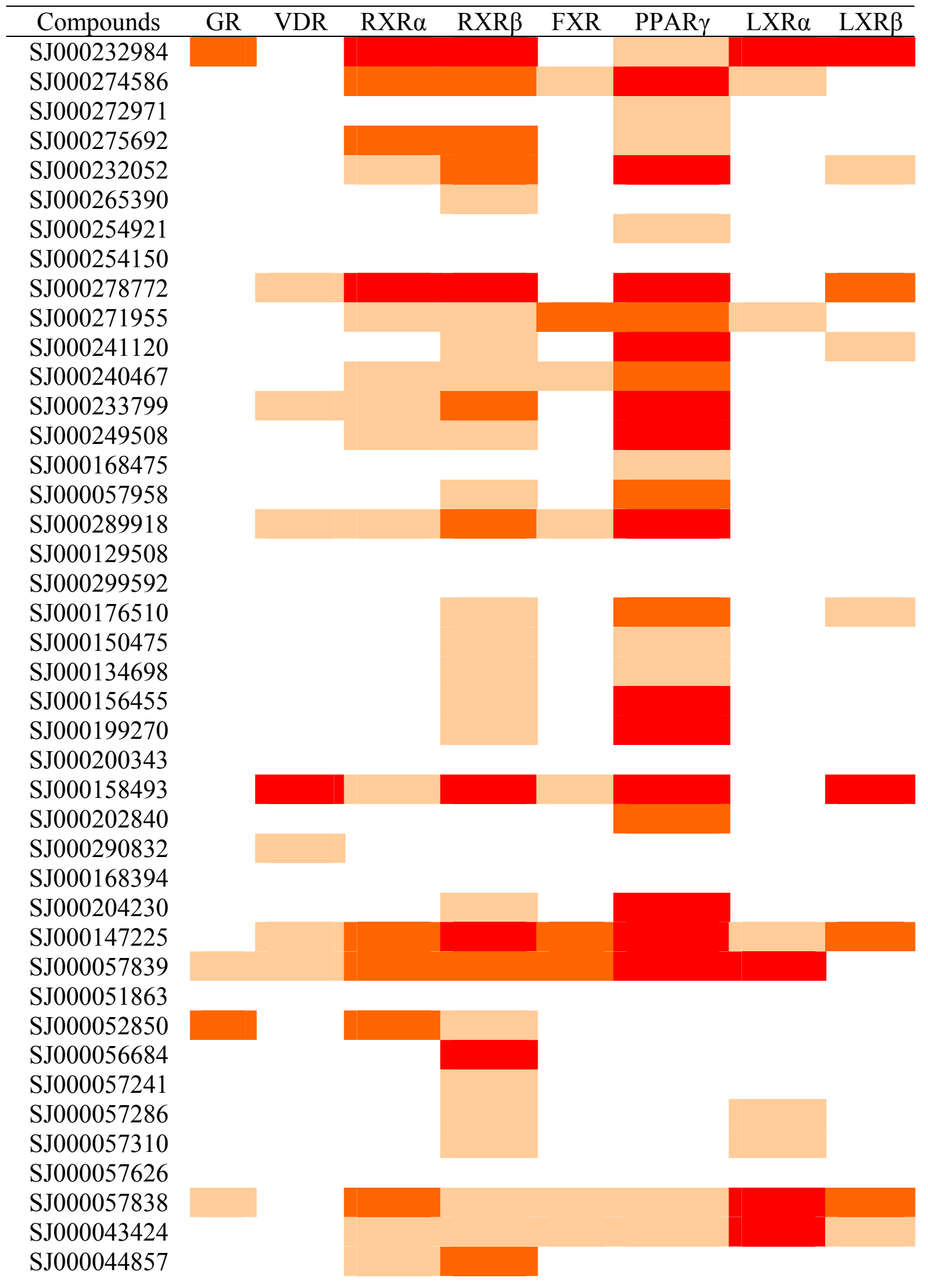


Table 3-2 (continued).

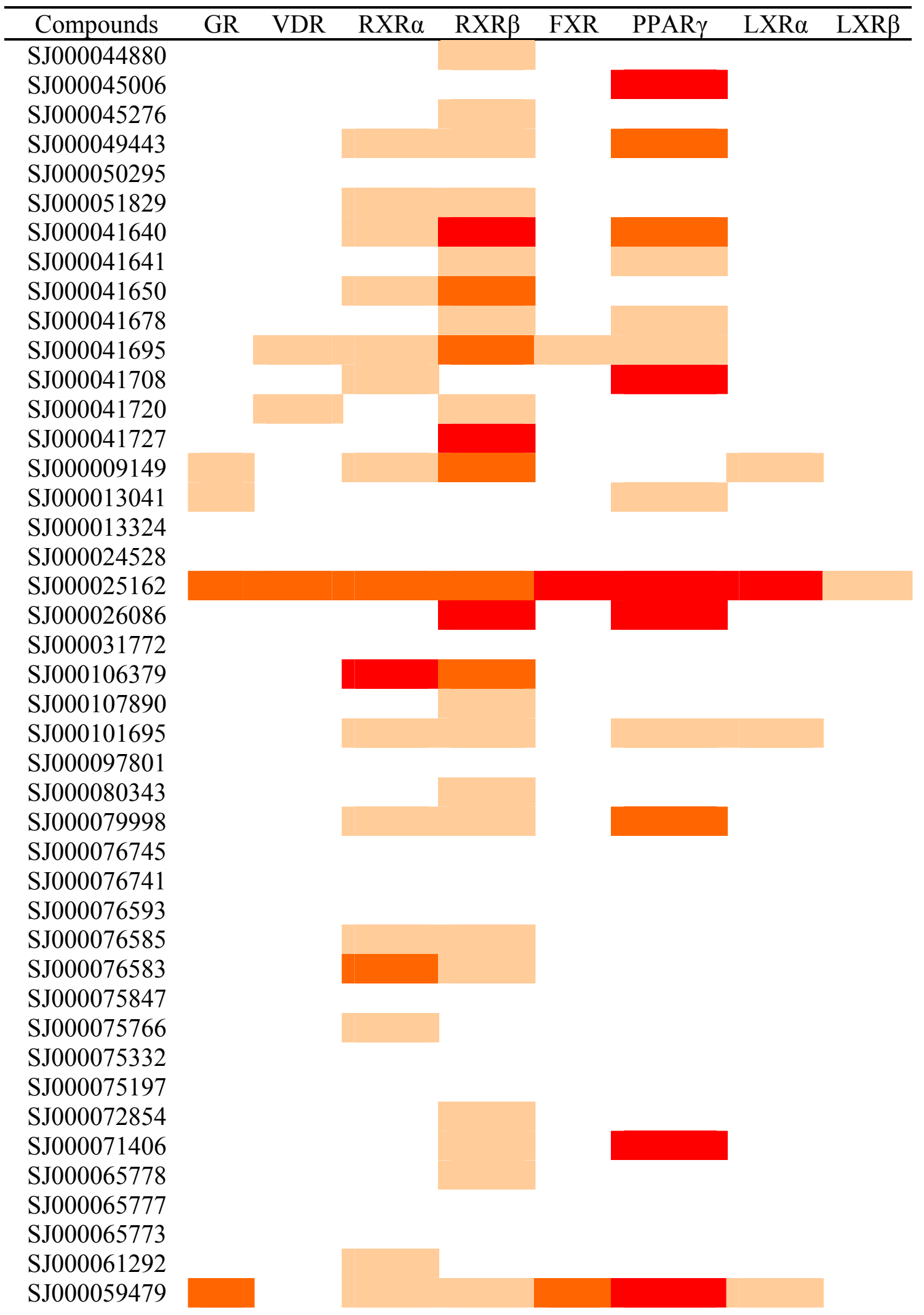


Table 3-2 (continued).

\begin{tabular}{ccccccccc}
\hline Compounds & GR & VDR & RXR $\alpha$ & RXR $\beta$ & FXR & PPAR $\gamma$ & LXR $\alpha$ & LXR $\beta$ \\
\hline SJ000059461 & & & & & & & \\
SJ000059404 & & & & & & & & \\
SJ000059367 & & & & & & & & \\
SJ000023063 & & & & & & \\
SJ000302340 & & & & & & \\
CMLD001455 & & & & & & & \\
CMLD001197 & & & & & & & \\
\hline
\end{tabular}

Note: At the highest concentration administrated $(40 \mu \mathrm{M})$, compounds that show less than $20 \%$ inhibition activity are colored white, $20 \%$ to $50 \%$ are tan, $50 \%$ to $80 \%$ are orange, and above $80 \%$ are red. Compounds colored white for all eight NRs are hits for the beta-lactamase reporter assay. 
SJ000129508

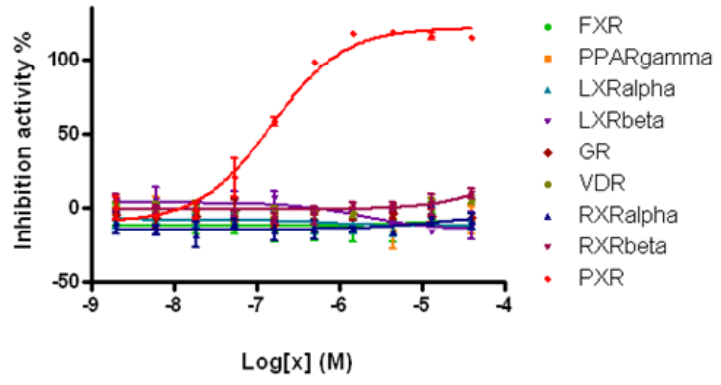

SJ000200343

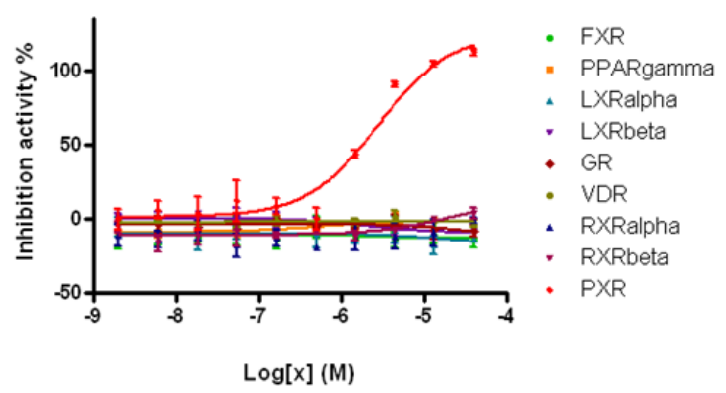

SJ000168394

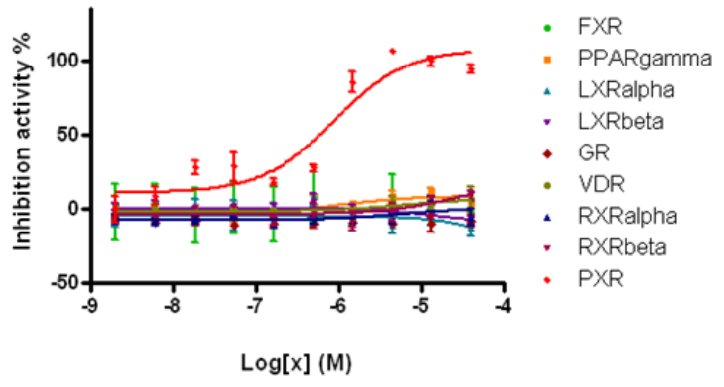

SJ000254150

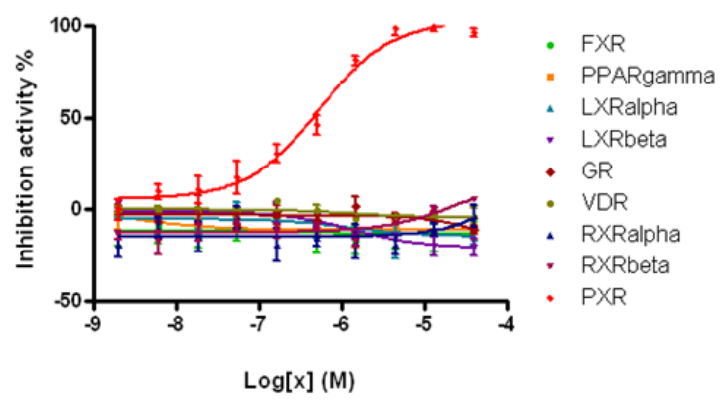

Figure 3-6. Specific PXR antagonists. The compounds didn't affect the transcriptional activity of the 8 nuclear receptors. They showed inhibition activity to PXR even at low concentration. The error bars stand for $\pm \mathrm{s}$. $\mathrm{d}$. 
SJ000025162

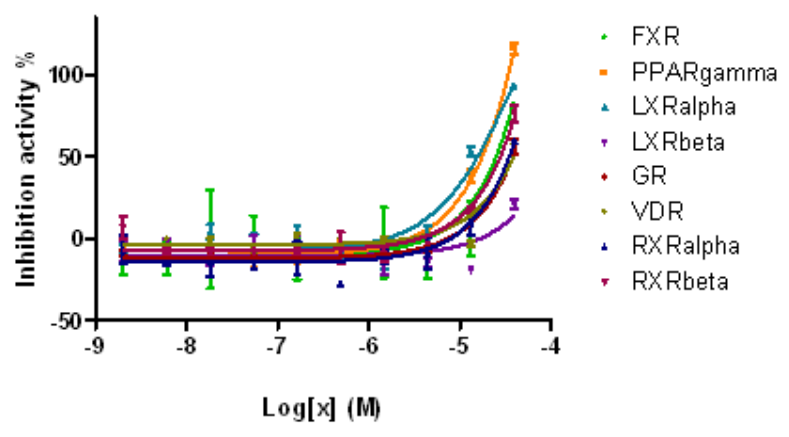

SJ000302340

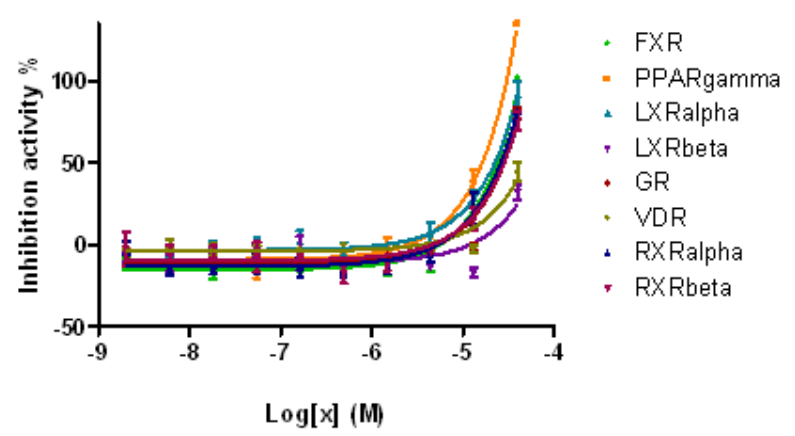

SJ000025162

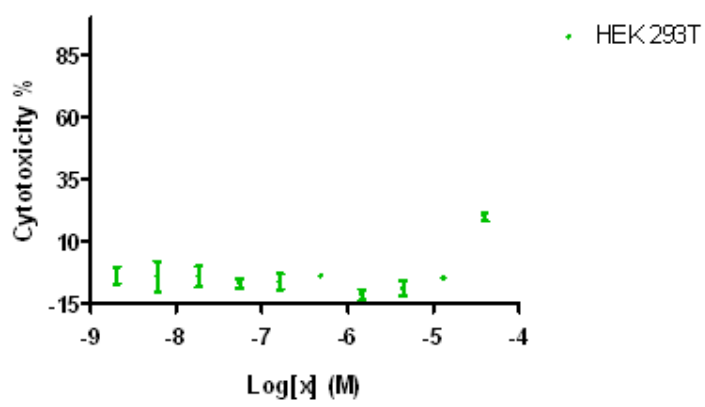

SJ000302340

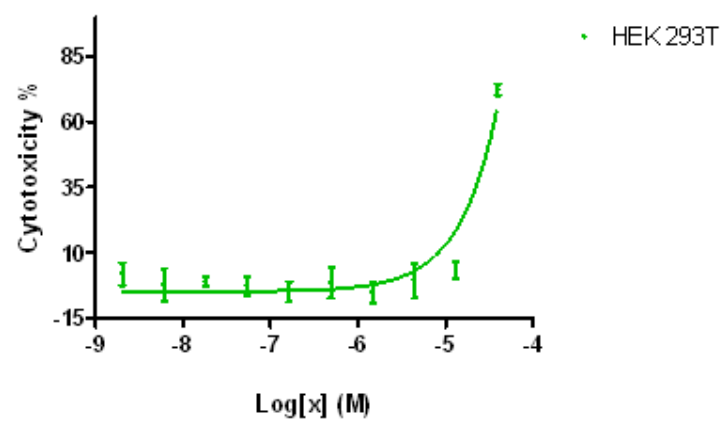

Figure 3-7. Compounds that showed inhibition activity to all cell lines in the assay. SJ000025162 and SJ000302340 showed inhibition activity to all eight nuclear receptors. SJ000025162 is $40 \%$ toxic to cells at $40 \mu \mathrm{M}$. It's not toxic up to $10 \mu \mathrm{M}$. It probably inhibited the transcriptional activity of at least some of the eight nuclear receptors. SJ000302340 is toxic to HEK 293T cell above $10 \mu \mathrm{M}$. The inhibition is probably due to its cytotoxicity. The error bars stand for $\pm \mathrm{s}$. $\mathrm{d}$. 
receptors remains unknown. Compound SJ000025162 showed high inhibition activity but it was only $20 \%$ toxic to HEK $293 \mathrm{~T}$ cells at the $40 \mu \mathrm{M}$. It suggested that this compound was an antagonist for all the nuclear receptors in this assay.

Most of these compounds can inhibit the activity of RXR $\beta$ (60) and PPAR $\gamma$ (47). It might suggest some structure similarity of the RXR $\beta$, PPAR $\gamma$ and PXR. Among the 47 compounds that showed inhibition activity to PPAR $\gamma$ most of them are very potent just like their inhibition ability to PXR. Through this reporter gene assay, not only did we identified the compounds that are specific to PXR we also got the information of their effects to other eight nuclear receptors. It can be used to identify the antagonists for other nuclear receptors as well. 


\section{LIST OF REFERENCES}

1. Enmark, E. and J.A. Gustafsson, Orphan nuclear receptors--the first eight years. Mol Endocrinol, 1996. 10(11): p. 1293-307.

2. Evans, R.M., The steroid and thyroid hormone receptor superfamily. Science, 1988. 240(4854): p. 889-95.

3. Mangelsdorf, D.J. and R.M. Evans, The RXR heterodimers and orphan receptors. Cell, 1995. 83(6): p. 841-50.

4. Kliewer, S.A., et al., An orphan nuclear receptor activated by pregnanes defines a novel steroid signaling pathway. Cell, 1998. 92(1): p. 73-82.

5. Bertilsson, G., et al., Identification of a human nuclear receptor defines a new signaling pathway for CYP3A induction. Proc Natl Acad Sci U S A, 1998. 95(21): p. 12208-13.

6. Blumberg, B., et al., SXR, a novel steroid and xenobiotic-sensing nuclear receptor. Genes Dev, 1998. 12(20): p. 3195-205.

7. Giguere, V., Orphan nuclear receptors: from gene to function. Endocr Rev, 1999. 20(5): p. $689-725$.

8. Iyer, M., E.J. Reschly, and M.D. Krasowski, Functional evolution of the pregnane X receptor. Expert Opin Drug Metab Toxicol, 2006. 2(3): p. 381-97.

9. Baker, A.R., et al., Cloning and expression of full-length $c D N A$ encoding human vitamin D receptor. Proc Natl Acad Sci U S A, 1988. 85(10): p. 3294-8.

10. Smith, D.P., et al., A novel nuclear receptor superfamily member in Xenopus that associates with $R X R$, and shares extensive sequence similarity to the mammalian vitamin D3 receptor. Nucleic Acids Res, 1994. 22(1): p. 66-71.

11. Ma, X., J.R. Idle, and F.J. Gonzalez, The pregnane X receptor: from bench to bedside. Expert Opin Drug Metab Toxicol, 2008. 4(7): p. 895-908.

12. Geick, A., M. Eichelbaum, and O. Burk, Nuclear receptor response elements mediate induction of intestinal MDR1 by rifampin. J Biol Chem, 2001. 276(18): p. 14581-7.

13. Staudinger, J., et al., Coordinate regulation of xenobiotic and bile acid homeostasis by pregnane X receptor. Drug Metab Dispos, 2001. 29(11): p. 1467-72.

14. Teng, S., V. Jekerle, and M. Piquette-Miller, Induction of ABCC3 (MRP3) by pregnane $X$ receptor activators. Drug Metab Dispos, 2003. 31(11): p. 1296-9.

15. Xie, W., et al., Reciprocal activation of xenobiotic response genes by nuclear receptors SXR/PXR and CAR. Genes Dev, 2000. 14(23): p. 3014-23.

16. Niemi, M., et al., Pharmacokinetic interactions with rifampicin : clinical relevance. Clin Pharmacokinet, 2003. 42(9): p. 819-50.

17. Backman, J.T., K.T. Olkkola, and P.J. Neuvonen, Rifampin drastically reduces plasma concentrations and effects of oral midazolam. Clin Pharmacol Ther, 1996. 59(1): p. 7-13.

18. Grub, S., et al., The interaction of saquinavir (soft gelatin capsule) with ketoconazole, erythromycin and rifampicin: comparison of the effect in healthy volunteers and in HIVinfected patients. Eur J Clin Pharmacol, 2001. 57(2): p. 115-21.

19. Polk, R.E., et al., Pharmacokinetic Interaction between amprenavir and rifabutin or rifampin in healthy males. Antimicrob Agents Chemother, 2001. 45(2): p. 502-8.

20. Ruschitzka, F., et al., Acute heart transplant rejection due to Saint John's wort. Lancet, 2000. 355(9203): p. 548-9. 
21. Crippin, J.S., Acetaminophen hepatotoxicity: potentiation by isoniazid. Am J Gastroenterol, 1993. 88(4): p. 590-2.

22. Guo, G.L., et al., Enhanced acetaminophen toxicity by activation of the pregnane $X$ receptor. Toxicol Sci, 2004. 82(2): p. 374-80.

23. Lee, W.M., Acetaminophen and the U.S. Acute Liver Failure Study Group: lowering the risks of hepatic failure. Hepatology, 2004. 40(1): p. 6-9.

24. Goldstein, J.A., Clinical relevance of genetic polymorphisms in the human CYP2C subfamily. Br J Clin Pharmacol, 2001. 52(4): p. 349-55.

25. Mu, Y., et al., Traditional Chinese medicines Wu Wei Zi (Schisandra chinensis Baill) and Gan Cao (Glycyrrhiza uralensis Fisch) activate pregnane X receptor and increase warfarin clearance in rats. J Pharmacol Exp Ther, 2006. 316(3): p. 1369-77.

26. Zhang, B., W. Xie, and M.D. Krasowski, PXR: a xenobiotic receptor of diverse function implicated in pharmacogenetics. Pharmacogenomics, 2008. 9(11): p. 1695-709.

27. Lim, Y.P. and J.D. Huang, Interplay of pregnane X receptor with other nuclear receptors on gene regulation. Drug Metab Pharmacokinet, 2008. 23(1): p. 14-21.

28. Zhang, J., et al., The human pregnane X receptor: genomic structure and identification and functional characterization of natural allelic variants. Pharmacogenetics, 2001. 11(7): p. 555-72.

29. Fukuen, S., et al., Identification of the novel splicing variants for the hPXR in human livers. Biochem Biophys Res Commun, 2002. 298(3): p. 433-8.

30. Hustert, E., et al., Natural protein variants of pregnane X receptor with altered transactivation activity toward CYP3A4. Drug Metab Dispos, 2001. 29(11): p. 1454-9.

31. Mensah-Osman, E.J., et al., Expression levels and activation of a PXR variant are directly related to drug resistance in osteosarcoma cell lines. Cancer, 2007. 109(5): p. 957-65.

32. Masuyama, H., et al., Down-regulation of pregnane X receptor contributes to cell growth inhibition and apoptosis by anticancer agents in endometrial cancer cells. Mol Pharmacol, 2007. 72(4): p. 1045-53.

33. Chen, Y., et al., Human pregnane X receptor and resistance to chemotherapy in prostate cancer. Cancer Res, 2007. 67(21): p. 10361-7.

34. Masuyama, H., et al., Expression and potential roles of pregnane $X$ receptor in endometrial cancer. J Clin Endocrinol Metab, 2003. 88(9): p. 4446-54.

35.Chen, T., Nuclear receptor drug discovery. Curr Opin Chem Biol, 2008. 12(4): p. 418-26.

36. Synold, T.W., I. Dussault, and B.M. Forman, The orphan nuclear receptor $S X R$ coordinately regulates drug metabolism and efflux. Nat Med, 2001. 7(5): p. 584-90.

37. Tabb, M.M., et al., Highly chlorinated PCBs inhibit the human xenobiotic response mediated by the steroid and xenobiotic receptor (SXR). Environ Health Perspect, 2004. 112(2): p. 163-9.

38. Huang, H., et al., Inhibition of drug metabolism by blocking the activation of nuclear receptors by ketoconazole. Oncogene, 2007. 26(2): p. 258-68.

39. Wang, H., et al., Activated pregnenolone X-receptor is a target for ketoconazole and its analogs. Clin Cancer Res, 2007. 13(8): p. 2488-95.

40. Zhou, C., et al., The dietary isothiocyanate sulforaphane is an antagonist of the human steroid and xenobiotic nuclear receptor. Mol Pharmacol, 2007. 71(1): p. 220-9.

41. Wang, H., et al., The phytoestrogen coumestrol is a naturally occurring antagonist of the human pregnane X receptor. Mol Endocrinol, 2008. 22(4): p. 838-57. 
42. Ekins, S., et al., Computational discovery of novel low micromolar human pregnane $X$ receptor antagonists. Mol Pharmacol, 2008. 74(3): p. 662-72.

43. Ekins, S., et al., Human pregnane X receptor antagonists and agonists define molecular requirements for different binding sites. Mol Pharmacol, 2007. 72(3): p. 592-603.

44. Xie, W., et al., An essential role for nuclear receptors $S X R / P X R$ in detoxification of cholestatic bile acids. Proc Natl Acad Sci U S A, 2001. 98(6): p. 3375-80.

45. Stedman, C.A., et al., Nuclear receptors constitutive androstane receptor and pregnane $X$ receptor ameliorate cholestatic liver injury. Proc Natl Acad Sci U S A, 2005. 102(6): p. 2063-8.

46. Ourlin, J.C., et al., The small heterodimer partner interacts with the pregnane X receptor and represses its transcriptional activity. Mol Endocrinol, 2003. 17(9): p. 1693-703.

47. Kamiya, A., Y. Inoue, and F.J. Gonzalez, Role of the hepatocyte nuclear factor 4alpha in control of the pregnane X receptor during fetal liver development. Hepatology, 2003. 37(6): p. 1375-84.

48. Staudinger, J.L., et al., The nuclear receptor PXR is a lithocholic acid sensor that protects against liver toxicity. Proc Natl Acad Sci U S A, 2001. 98(6): p. 3369-74.

49. Xie, W., et al., Humanized xenobiotic response in mice expressing nuclear receptor SXR. Nature, 2000. 406(6794): p. 435-9.

50. Kliewer, S.A., B. Goodwin, and T.M. Willson, The nuclear pregnane X receptor: a key regulator of xenobiotic metabolism. Endocr Rev, 2002. 23(5): p. 687-702.

51. Ma, X., et al., The PREgnane X receptor gene-humanized mouse: a model for investigating drug-drug interactions mediated by cytochromes P450 3A. Drug Metab Dispos, 2007. 35(2): p. 194-200.

52. Gong, H., et al., Orphan nuclear receptor pregnane X receptor sensitizes oxidative stress responses in transgenic mice and cancerous cells. Mol Endocrinol, 2006. 20(2): p. 27990.

53. Wilkinson, J.M., et al., Compound profiling using a panel of steroid hormone receptor cell-based assays. J Biomol Screen, 2008. 13(8): p. 755-65. 


\section{APPENDIX. SUPPLEMENTAL DATA FOR CHAPTER 3}

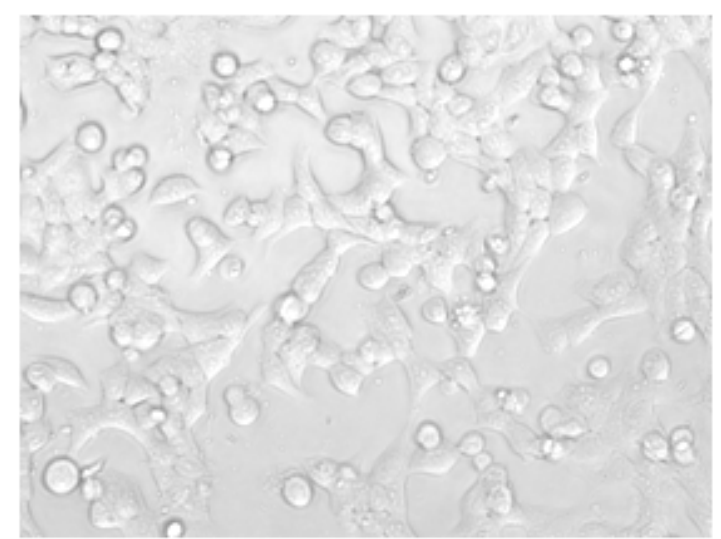

Poly-D-Lysine plate

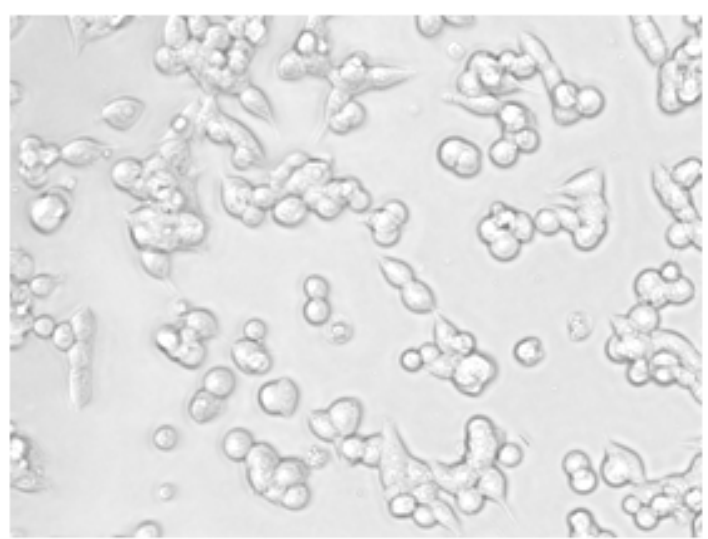

regular plate

Figure A-1. Cell growth on different assay plates. 10,000 per well LXR $\alpha$ cells were seeded in Poly-D-Lysine coated and regular black-wall, clear bottom plate respectively. Images were taken after 16 hours incubation. 

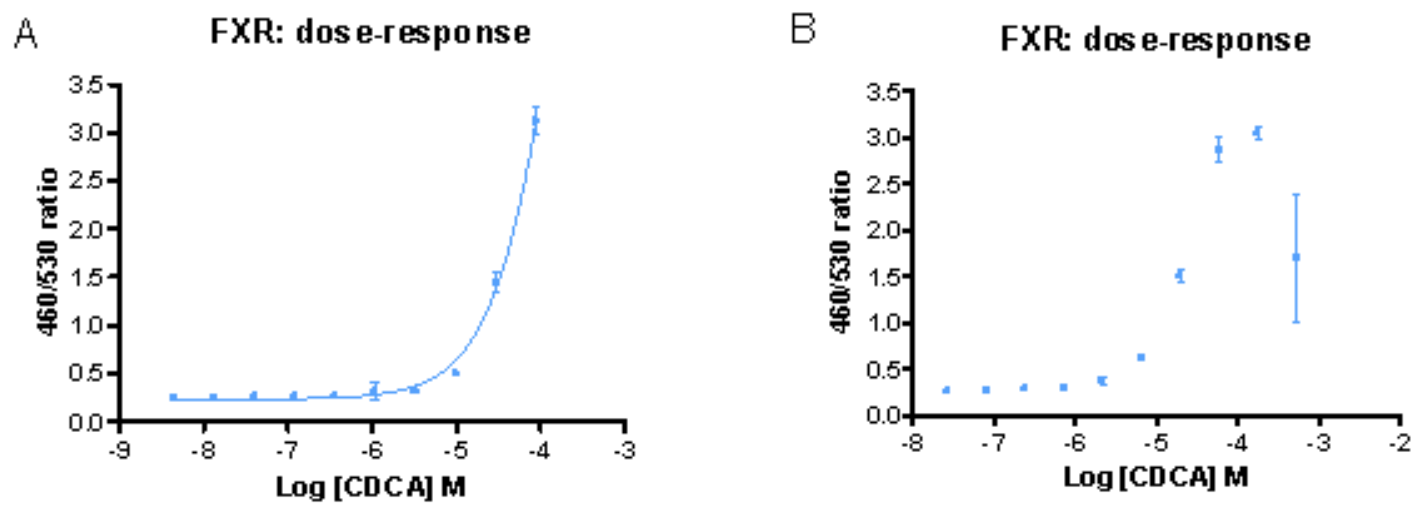

Figure A-2. Dose response curve of CDCA to FXR. A. When using reported maximum stimulation concentration of CDCA to FXR, the activation activity can not be saturated. B. After increased the concentration of CDCA used to stimulate FXR, the agonist showed cytocoxicity. 


\section{VITA}

Fang Lei was born in Kaijiang, Sichuan Province of P. R. China in 1980. She attended the Integrated Program in Biomedical Sciences at University of Tennessee Health Science Center for graduate studies in Aug. 2007. She is expected to obtain her Master of Science degree in May 2009. 